\title{
A MAGYARORSZÁGI BAROKK KASTÉLYOK REPREZENTATÍV TÉRRENDSZERÉNEK MEGÚJÍTÁSA 1750 ÉS 1840 KÖZÖTT
}

\author{
FEKETE J. CSABA*
}

Az 1750-es és 1840-es évek közötti időszak magyarországi foúri lakóhelyépítészetében a reprezentatív közösségi terek tér és rendeltetésének összefüggéseit elemezve egy átalakulási - fejlődési vonal figyelhető meg. Ez a XVIII. századi hierarchikus elvű barokk hosszirányú térfüzési mód, valamint a XIX. század második felének historizáló központos tércsoportosítással korszerűen kialakuló térkompozíciók között mutat szerves átmenetet.

A fejlődés első állomásaként, az 1750-60-as években, az előudvaros diszpozíciók elterjedésével, a kocsibehajtó-csarnokokat felváltotta a központi fekvésü sala terrena előcsarnok rendeltetéssel (Kiscenk, [ma Nagycenk] Gyula, Mór). A főlépcsőház - mivel a női és a vendégszint továbbra is az emelet volt - ekkor még őrizte a térkompozícióban elfoglalt hangsúlyos szerepét. Az 1780-as évektől gyakrabban, a XIX. század legelejétől kezdve pedig szinte kizárólagosan került a földszintre, a kerttel egyre közvetlenebb, nemcsak vizuális, hanem fizikai kapcsolatba a kastély fő szintje (Csákvár). Ez szükségszerüen eredményezte a közösségi- és lakórendeltetések elhelyezésének differenciálását. Az épület szimmetriatengelyét elfoglaló sala terrena a lakóterek sorába integrálódott, s legtöbbször (hagyományosan) ebédlő szerepét töltötte be, két oldalán közvetlen átjárással a kétnemü lakosztályok nappali és hálószobái felé. A belső tér egyszerre vált intimebbé és átjárhatóbbá belül, mind nyitottabbá kívülre, a kert felé.

A XIX. század első negyedének társasági és lakórendeltetései hosszirányú kompozícióban hierarchikus tagozódás nélkül, egymás mellé rendelt elemekként sorakoztak (Bicske, Dég). A terek önálló formálása, a lakó és társasági rendeltetések funkcionális szétválasztása e kompozícióban valósult meg először hazánkban. A térsorolás tengelyének törésével, az épülettraktus kettőzésével összefogottabb téralakításra is lehetőség nyílt (Gyöngyös). Ezt pedig már csak egy lépés választotta el a XIX. század közepének következő jelentős belső-térszerkezeti újításától, a társasági tereket monumentális csoportba foglaló, központos térkompozíciók kialakulásától.

Kulcsszavak: sala terrena, térrendszer, kastély, tipológiai vázlat

* okl. építészmérnök, múemlékvédelmi egyetemi szakmérnök. BME Építészmérnöki Kar, Építészettörténeti és Múemléki Tanszék. 1111 Budapest, Múegyetem rkp. 3. K. II. 60. Tel.: 463-1330, fax: 463-1638; e-mail: fecsajo@freemail.hu 
A historizmus építészete számos olyan feladattal foglalkozott, mely új problémaként jelentkezett, és amelynek megoldására az elmúlt korok még nem jelöltek ki kellően magalapozott utat. A kastélyépítés nem tartozott ezek körébe, hagyományos építészeti feladatnak számított. „Ennek ellenére mégis azt látjuk, hogy az 1800 után épült kastélyok - írta Rados Jenő 1943-ban - mind alaprajz, mind pedig felépítés tekintetében gyökeresen eltérnek az előző korok hasonló alkotásaitól. Az eltérés oly szembeötlő és a változott viszonyokra annyira jellegzetes, hogy nem térhetünk ki részletesebb megvilágítása elől..."

Rados Jenő határozta meg elsőként a XIX. század első felének magyar kastélytípusát. „Palladio tiszta architekturájának nemzetivé alakult felvirágzásával állunk szemben, melynek a kor divatjánál mélyebbre nyúló gyökereit részben főuraink erős angol irányú érdeklődésében kell keresnünk - hisz Angliában a vicenzai mester tanait még a barokk fénykor idején is ${ }^{2}$ rendkívül tisztelték - de bizonyos, hogy a stílus alakulására építészetünk akkori vezéralakjának, Pollack Mihálynak olaszországi tanulmányévei is erős befolyással voltak.” Máshol így fogalmazott: „A szükség követelte egyszerüség és a belőle kikristályosodó építészeti stílus annyira összeforrt a magyar talajjal és egységes hazai kialakításban viszonyainkat oly híven fejezte ki, hogy a Palatinus-kori kastély magyar típusát kell benne látnunk. (Alcsút, Lovasberény, Dég, Csákvár, Hegyfalu, Fót, Gyömrő, Rohó [ma Rohov, SK].) E jellegzetesen magyar elrendezés különféle változataiban két egymástól eltérő csoportot kell szembeállítanunk: a nagyobb méretű emeletes kastélyt a földszintes kiskastéllyal, az ún. kúriával."4

Az építési program léptékének és az épülettömegek elrendezésének összefüggéseit elemezve Rados Jenő észrevette, hogy ahol az építési programot sok helyiség létesítésével és nagy beépített alapterülettel két szintben kellett megoldani, az építész terve e korszakban is változatosabb lehetett. A nagyobb kastélyoknál a tömegek U-alakban való elrendezése barokk hagyományként maradt meg. Mivel a kastély kerti homlokzata mindig a középrizalit oszloprendjének az épület magasságából adódó arányaihoz igazodott, síkjába csak olyan épülethosszat lehetett bevonni, mely egy tekintettel átfogható kompozíciós egységet alkotott. Ha több helyiségre volt szükség, azokat az U-alakban hátravetett szárnyakba, vagy különösen igényes és nagyszabású kívánságok esetén, annak ismételt derékszögü töréseivel egy második, a homlokzatnak mintegy hátteréül szolgáló, hátrahúzott homlokzat mögé helyezték el. A hátranyúló szárnyak és a középrész viszonyának megfelelő

Zádor-Rados 1943. 373.

2 Itt Rados Jenő, a mai fogalmainkkal a korai angol romantikus klasszicizmusként (palladianizmus) jellemzett korszak jelentékeny tervező egyéniségére, Robert Adam építészre (1728-1792) és ismert épületeire gondolhatott.

3 Rados 1931. 15.

4 Zádor-Rados 1943. 376. 
kialakításával volt biztosítható a befoglaló formák legkedvezőbb aránya. Ahol meglévő épületek átalakítása történt a korszakban, találkozunk olyan megoldással, amelynél az egyes részek önálló, külön tömegekké alakultak (például Lovasberény, Csákvár, Acsád, Bajna).

A folyosóra mint összekötő láncra egyoldalt felfüzött helyiségek sorozata is nagyobb változás nélkül ment át e korszakba. Rados Jenő szerint a reformkor kastélya a barokknak sok vonatkozásban mégis merő ellentéte volt. A középső termet a kerttől csak néhány lépcsőfok és a nyitott oszlopcsarnok választotta el, és méreteiben sem vált el annyira a melléje sorakozó többi helyiségtől. Fontos észrevételei, hogy a nagyszabású díszlépcső - mely a barokk kastély gerince volt - most ,elesett" és így az egész alaprajz kötöttsége felbomlott, s ezáltal a szobáknak és termeknek kötetlenebb egymás mellé helyezése vált lehetségessé. „Ami, ha bizonyos vonatkozásokban nyereségnek is tekinthetö, végeredményben a szerves egység meglazulását jelenti." A társadalmi élet céljaira szolgáló és fontosabb lakóhelyiségek a földszinten voltak, az emeletre pedig vendég- és személyzeti szobák kerültek. Az utóbbiak megközelítésére csak olyan lépcső készült, amilyenre feltétlenül szükség volt. „Az egész alaprajzi és felépítési elrendezésben nyomatékkal érvényesül annak kifejezésre juttatása, hogy a ház ura nem fóúri hatalmát akarja érzékeltetni, hanem a külsőségektől mindjobban eltávolodó emberi és a természetbe kapcsolódó életmód lehetőségét kívánja megtalálni otthonában..."5

Voit Pál 1943-ban tett igen rövid észrevétele fontos: „Egyrészt a foúri palota belső szerkezetében kettévált: külön reprezentációs, társasági részre s az ettől berendezésben és elhelyezésben különálló lakó- és hálószobákat magábanfoglaló otthonterületre... A társasági részt ... csak fogadások, ünnepélyek alkalmával használták..."6

Az ún. klasszicista kastélyok térszerkezetének jellegzetességeiről alkotott képünk Rados Jenőt követően, a XX. század második felében, újabb megállapításokkal alig bővült, illetve alig vált árnyaltabbá. Ezek közvetlen klasszicizáló késő barokk ${ }^{7}$ - ún. copf - előzményeivel pedig, szinte nem is foglalkoztak. Egyetlen kivétel, Révhelyi (Réh) Elemér, a hazai barokk és késő barokk építészet kutatója, akinek feltünt a Rados Jenő által korábban említett jelentős változás egyik állomása, mikor ezt írja: „Fellner ... 1762-ben építi fel a móri Lamberg kastélyt. A manzárdtetős épület alaprajza már eltérést mutat az előkelő reprezentálást kifejező kastélytípusoktól. Az épület tömege fordított U-alakú. A bejárat felőli cour d' honneur hatását földszinti árkádsor emeli, ebben népies, helyesebben provinciális ízt kölcsönöz a megjelenésnek és a kastély belső élete közvetlen kapcsolatba kerül a min-

Zádor-Rados 1943. 375-376.

6 Voit 1943. 262

7 Hazánkban az 1760-1800 közötti időszak kastélyépítészete a XX. század második felében meghatározott, ún. romantikus klasszicizmus stíluskategóriával jellemezhető korszerübben. 
dennapi élettel és nem zárkózik el attól." ${ }^{8}$ Látható azonban, hogy Révhelyi (Réh) Elemér figyelmét a külső formajegyek terelik el a belső térszerkezet további jellegzetességeiről.

Kelényi György 1974-ben, Koppány Tibor 1990-ben, valamint 1998-ban Horváth Hilda is egymást, illetve Rados Jenőt követve egyetértettek abban, hogy a kastélyok alaprajzain szimmetria uralkodik. Az épülettömb szabályos formájának a belsőben is szabályos, szimmetrikus elrendezés felel meg. A klasszicista kastélyaink még sokat megőriztek a barokk elrendezésből. A díszterem ugyanúgy centruma a kompozíciónak, mint korábban, s a teremsorból és folyosóból álló kéttraktusos alaprajz is általános. Kelényi György megfigyelése szerint a helyiségek többnyire négyszögletesek voltak. Az ovális vagy sokszög-alaprajzú termek jóformán eltüntek a barokk megszüntével. Csak a kör alakú - tehát a négyszögleteshez hasonlóan zárt, szabályos - terem maradt még meg. A dísztermek ilyen kialakítása volt gyakori (Dég, Kistapolcsány [ma Topol’èianky, SK]). „A termek zárt, négyszögletes alaprajza a tervezőnek azt a szándékát tanúsítja, hogy minden helyiség önmagában zárt, a többitől elkülönülő egységet képezzen. Még az egymásba nyíló termek sem alkotnak egymást kiegészítő-előkészítő teremsort. A szobák magassága, szélessége, mélysége hasonló, így a térérzékelésben a legcsekélyebb mozgás sincs... Többnyire néhány lépcső vezet fel a portikuszhoz... Nagy üvegajtók jelzik, hogy a XIX. század embere kitárulkozik a természet felé, s elég biztonságban érzi magát e közvetlen kapcsolatban. Innen az előcsarnokba jutunk, mely a kerti teremhez kapcsolódik... A termekben nyugalom uralkodik. A barokk térillúziót keltő, a határfalakat művészi eszközökkel kitágító szemlélete nem felel meg az új korszak igényeinek... Ehelyett minden falsík a valódi térviszonyokat igazolja, sőt, hangsúlyozza. A mennyezet vonala határozottan lezárja a teret, s nem kelti valótlan arányok illúzióját..."

Koppány Tibor szintén a barokk jellegzetességekből indult ki elemzésében. Szerinte általában megtartották a barokk idején kialakult alaprajzi formákat: a legáltalánosabb elrendezés az U-alaprajz maradt, de mind gyakrabban fordult elő a téglány forma is. Észrevette, hogy a reprezentatív díszterem olykor valamelyik oldalrizalit mögött helyezkedett el, akárcsak a lépcsőház, amely a portikusz mögötti kapualj vagy előcsarnok oldalára került. A klasszicista kastélyokban általában kevesebb lett a reprezentatív helyiségek száma és otthonosabb belsők épültek, több lakóhelyiséggel. A fontosabb közösségi termek (könyvtár, díszterem, biliárdszoba stb.) többnyire a földszinten voltak, a lakók így szorosabb kapcsolatba kerültek a természettel. „A klasszikus görög-római múvészet szigorúbb felfogása felé forduló ízlés módosította a reprezentáció iránti igényeket, s ennek hatására a

8 Kardos-Révhelyi 1952. 28.

9 Kelényi-1974. 24-26. 
belsőkben a barokk mozgalmasságát a tiszta, áttekinthető terekre való törekvés váltotta fel..."10 Lényegében Horváth Hilda is hagyományosnak tekinti, hogy a klasszicista térszervezés alapjában véve megtartotta a barokk térfüzés alapelveit a teremsorok között vízszintes, az emeletek között, pedig függőleges térkapcsolatot létesített. A korábbi stílusperiódusból - tehát a barokkból -átvették a kéttraktusos elrendezést - mivel a folyosó a szobasorral párhuzamosan futott -, a horizontális és vertikális térkapcsolást, a díszterem centrális elhelyezését. A változás szerinte abban nyilvánult meg, hogy bár a helyiségek, a termek összekapcsolódtak, önmagukban mégis zárt egységet képeztek. A négyszögletes alaprajzú termek a központi díszteremhez kapcsolódtak, de elvetették a négyszögletestől eltérő alaprajzot, így ritka volt a sokszögü vagy elliptikus tér. A dísztermek általában a klasszicista kastélyoknál is több szintet fogtak át, a helyiségeket pedig síkmennyezettel fedték. A térillúzió megszűnt, hiszen az egyes szobákat határozottan lezárták, és hangsúlyozták a falak térelhatároló feladatát. Az egymásba nyíló terek összefüggő, egységes térhatására, térillúziójára építő térkompozíciókat, valamint a lépcsőház kiemelt szerepét - a lépcső nem esett a főtengelybe - szintén nem alkalmazták a korszakban. A lépcsőfeljáró egyszerü volt, többé nem reprezentatív, s úgy tervezték, hogy funkciójának éppen megfeleljen. Az alaprajzot, a termek elhelyezését is a célszerüség, a puritanizmus és a szimmetria diktálta. ${ }^{11}$

\section{A BAROKK TÉRSZERKEZET HIERARCHIÁJÁNAK FELBOMLÁSA - A DIFFERENCIÁLTAN KEZELT EMELETES LAKÓ- ÉS TÁRSASÁGITÉR-KOMPOZÍCIÓK 1750 ÉS 1780 KÖZÖTT}

Hazánkban a kastélyok szabadon álló, francia rendszerű díszudvaros (cour d' honneur) elrendezésére - ahol az udvar előudvarként, a fó megközelítés irányából elsőként tárul fel, valamint fó- és melléképületszárnyak határolják - a XVIII. század első feléből kevés példát találunk. Ezek elsősorban jelentős bécsi építészek Johann Lucas von Hildebrandt (1668-1745), Anton Erhardt Martinelli (1684 k.-1747) vagy Franz Anton Pilgram (1699-1761) - alkotásai. ${ }^{12}$ A korszakban azonban jellemzőbb és elterjedtebb az ún. nyugat-dunántúli kastélytípus, melynek, mint magyar sajátosságnak jellegzetessége, hogy a díszudvar a föszárny mögött, a

\footnotetext{
${ }^{10}$ Dercsényi-Koppány-Hegyi 1990. 27-28.

${ }^{11}$ Horváth 1998. 22-27.

12 Féltorony [ma Halbturn, A], 1701-11; Ráckeve, 1701-02; Cseklész [Bernolákovo, SK], 1714-27; Süttör [ma Fertőd], 1720-21; Pápa, 1731-58.
} 
kerthez kapcsolódóan helyezkedik el, s feltárását a fó épületszárny tengelyében átvezetett kocsibehajtó(csarnok) biztosítja. ${ }^{13}$

A tipikus barokk - kocsibehajtó(csarnok)-lépcsőház(csarnok)-nagyteremlakosztályok - térszerkezetektől jelentős eltérést mutató, ma is álló XVIII. századi emeletes kastélyok sorát az 1741-1762 között, gróf Széchényi Antal (1714-1767) megbízásából épült kiscenki [ma Nagycenk] kastély új épülete nyitotta meg.

A kastély első tervváltozata ${ }^{14}$ nem valósult meg, de az épületben ma is olyan térszerkezet rajzolódik ki, mely a hagyományos barokk elemeket számos újító megoldással komponálja. ${ }^{15}$ A kastély 1793. évi inventáriuma ismert. Eszerint a háromrizalitos épület már középlépcsőházas (1) s folyosója is a mai helyén húzódott. Megvolt a keleti rizalit kétszintes kápolnája (7) is. Több helyiséggel bírt, mint ma, különösen az emeleten. Az inventárium a kápolnától indulva sorolja a földszinti helyiségeket, melyek közül az ötödik a biliárdszoba, a sala terrena (2) volt, az innen nyugatra eső helyiségekben is a háziszemélyzet lakott. A folyosó után a lépcsőt említik, majd innen a „Nagy Palota” elnevezésú nagyterembe (3) lépnek be. Innen nyugatra tartva mennek keresztül a grófné (4) szobáin, majd a nyugati rizalitban elhelyezett kisebb szobákat érintik. A nagyteremtől keletre a gróf szobái (5) következtek, köztük a könyvtárral, és a leltár az oratóriummal (6) fejeződik be. ${ }^{16}$

A kastély térrendszerében barokk hagyományként élt tovább a női szint emeletre helyezése és a kastély középhangsúlyának megtartása. A hagyományostól legszembetünőbb eltérés, legfőbb újítás az, hogy az épületbe már nincs lehetőség kocsibehajtásra. Az épület axisát - a teljes középrizalitot átfogó - földszinti nagyterem (sala terrena), mögötte a szimmetrikus elrendezésű, háromkarú lépcső csarnoktere foglalja el. A biliárdszobaként használt sala terrena, a feltárás e rendszerében a kert felől előcsarnok szerepü. ${ }^{17}$

13 (Vas)Szécseny, 1719-22; Magyarbél [Vel'ky Biel, SK], 1722-25; (Vas)Surány, 1723; Edelény, 1722-28; Gyülevíz [ma Zsira], 1739; Gács [Halič, SK], 1736; Bajna, 1742-43; Nagytétény, 1743-78; Gödöllö, 1752-59; Hatvan, 1754-57; Keszthely, 1755-68; Kisbér, 1762; Gyöngyös, 1769-70, melyek közül Bajna, Gödöllö, Hatvan, Keszthely, Kisbér, Gyöngyös kastélya utcavonalra épült.

${ }^{14}$ MOL T21 2. F. A. Pilgram terve, melyet bizonyára Széchényi Antal megbízására készített, az 1750 körüli évekből származik. Koncepciója azonban alapját képezhette az egyszerübb, elkészült épület tervének. (Krámer 1973. p. 483., Zsámbéky 1994. p. 139. 24.2. tétel.)

${ }^{15}$ MOL T21 13. Hefele Menyhért (1716-1794) építész 1791. évi (meg nem valósult) emeletráépítési tervén azonban ez a XVIII. századi épület meglehetős bizonyossággal értelmezhető. (Zsámbéky 1994. p. 139. 24.3. tétel.) Közli: Voit 1964. p. 256. 243. kép.

${ }^{16}$ Krámer 1973. p. 486.

${ }^{17}$ Földszinti nagyterem - sala terrena - előcsarnok rendeltetéssel sejthető 1740 körül gróf Barkóczy Ferenc (1710-1765) egri püspök Felsőtárkány melletti „Fuorcontrasti" kastélyában is, mely nem rezidencia, hanem emeletes mulatókastély (maison de plaisance) volt. A sala terrena ebben a müfajban is elnyeri egyik jellegzetes korabeli rendeltetésformáját, előcsarnok szerepét. (Sugár 1996. pp. 107-121.) 


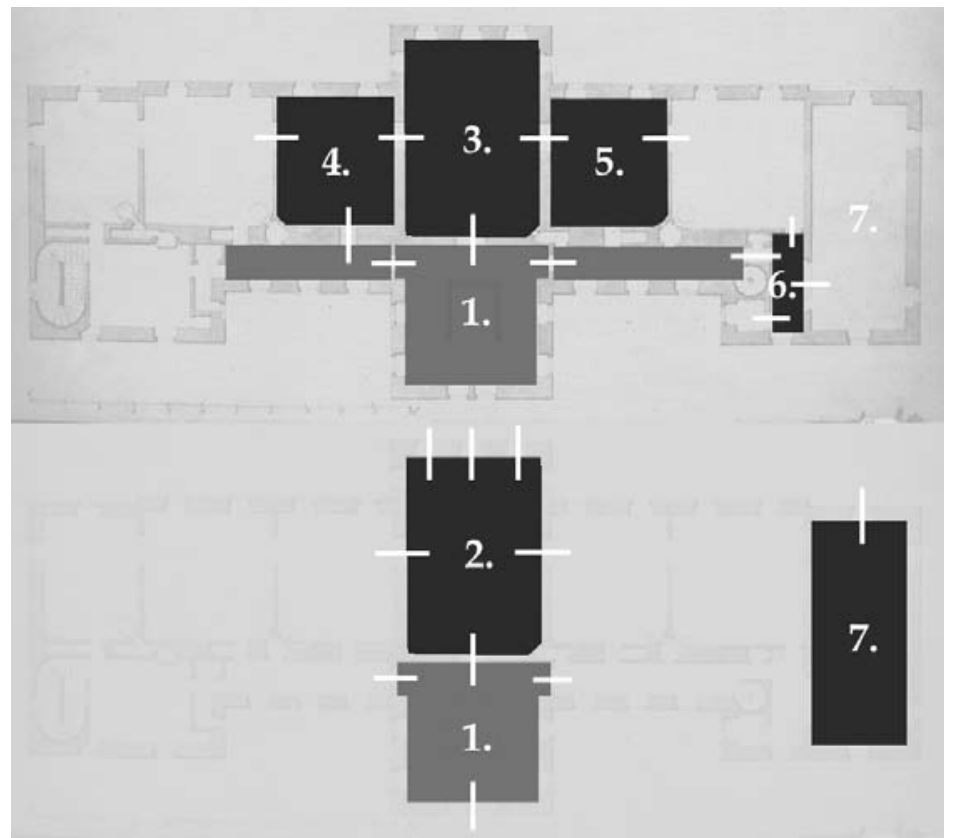

1. ábra. A kiscenki kastély földszintje (lent) és emelete (lent), Hefele Menyhért, 1791 (elemzés F. Cs.)

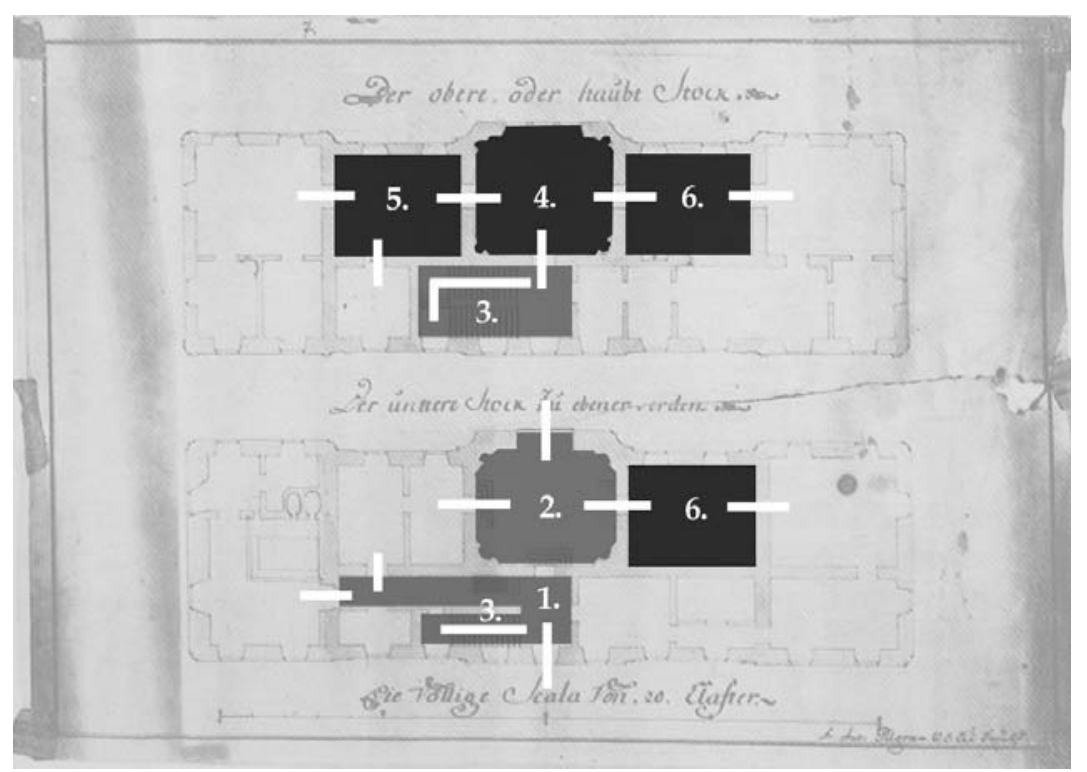

2. ábra. F. A. Pilgram, Wieden (elemzés F. Cs.) 
F. A. Pilgram a Bécs melletti Wiedenbe ${ }^{18}$ a XVIII. század közepén a Károlyiaknak áttervezett kastélyán, az épület axisában szintén sala terrena (2), előcsarnok rendeltetéssel látható, mely előtt kétkarú, aszimmetrikus lépcsőház $(1,3)$ vezet az emeleti nagyteremhez (4), s az ahhoz kapcsolódó női (5) és férfi (6) nappali szobákhoz. ${ }^{19}$

Feltehetően F. A. Pilgram múve az a tervsorozat is, mely összetett, francia rendszerü kastélyt mutat több irányból megközelíthető díszudvarral, főtengelybe állított lépcsőházcsarnok, valamint földszinti nagyterem téregyüttesével. ${ }^{20}$

Harruckern Ferenc (1696-1775) báró gyulai régi kastélyán a XVIII. század második harmadában egy nagyszabású kiépítést tervezett, amelyhez Franz Anton Hillebrandt (1719-1797) által 1760-62-ben készített tervsorozata ismert. ${ }^{21}$

A tervek szintén a hagyományos elemek új kompozícióját mutatják. ${ }^{22}$ A szokásos barokk kapualj itt is elmaradt, s az épületbe történő behajtás lehetősége helyett kocsieléhajtó (1) látható. A fóbejárati széles ajtó egy aszimmetrikus elhelyezésú kétkarú lépcső - melyre már találunk korábbi példákat - szük terébe (2) vezet. Az épület axisában, a lépcsőház mögött, a kert felöl - a teljes középrizalitot elfoglaló - földszinti ebédlő nagyterem, sala terrena (3) nyílik. Itt ez köti össze a nyugati kiszolgáló szárnyat a keleti lakószárnnyal. Előbbi végében az udvari nagykonyha, utóbbiban kétszintes kápolna (8) és oratórium (7) zárja a térsort. Az emelet közepét a nagy táncterem (4) a lakosztályok nappali szobáinak $(5,6)$ enfilade füzérében foglalja el.

Ugyanezekben az években, 1763-ban gróf Esterházy Miklós (1711-1764) megbízásából Tatán, az országban páratlanul nagy léptékủ kastélyt tervezett Fellner Jakab (1722-1780). Tervváltozatai fényképfelvételeken maradtak fenn. ${ }^{23}$ Az épületterv a fent bemutatott térkompozíció igen nagy léptéke, valamint a helyszín épített előzményeit elsősorban a környezetalakításban (tó, díszkert) figyelembevevő merészsége miatt különös figyelmet érdemel.

A Révhelyi (Réh) Elemér által elnevezett négy variáns közül a II. és IV. tervvariáns olyan, szintenként 3-3 lakosztályt befogadó épületet mutat, amelynek reprezentatív vendégforgalma koncepciójában azonos térsorban valósulhatott volna meg. A kas-

18 Jávor 1995. pp. 192--209.

19 MOL T20 7. Közli: Voit 1964. p. 255. 242. kép; Voit 1980. p. 152. 110. kép.

${ }^{20}$ MÉM Ltsz. 72.020.10. és 72.020.14. A tervek F. A. Hillebrandt kamarai fóépítész kezén jutottak hazánkba. Közli: Voit 1980. pp. 166-167. 130-131. kép.

${ }^{21}$ MOL T20 57: 1-11. Közli: Voit 1980. pp. 145-147. 106/d-e, h. kép.

22 A kastély a térszerkezet néhány jelentéktelenebb változtatásával - szimmetrikus lépcsőházzal, 5 helyett 3 axisos nagyteremmel, kisebb szobaszámmal stb. - a terven ábrázolt formában később épült ki.

${ }^{23}$ A rajzok eredeti példányai az Esterházy-levéltár 1945. évi megégésekor elvesztek, de szerencsére Révhelyi (Réh) Elemér fotókópiái fennmaradtak. Közli: Haris-Pusztai 1988. pp. 74-76, 78. 

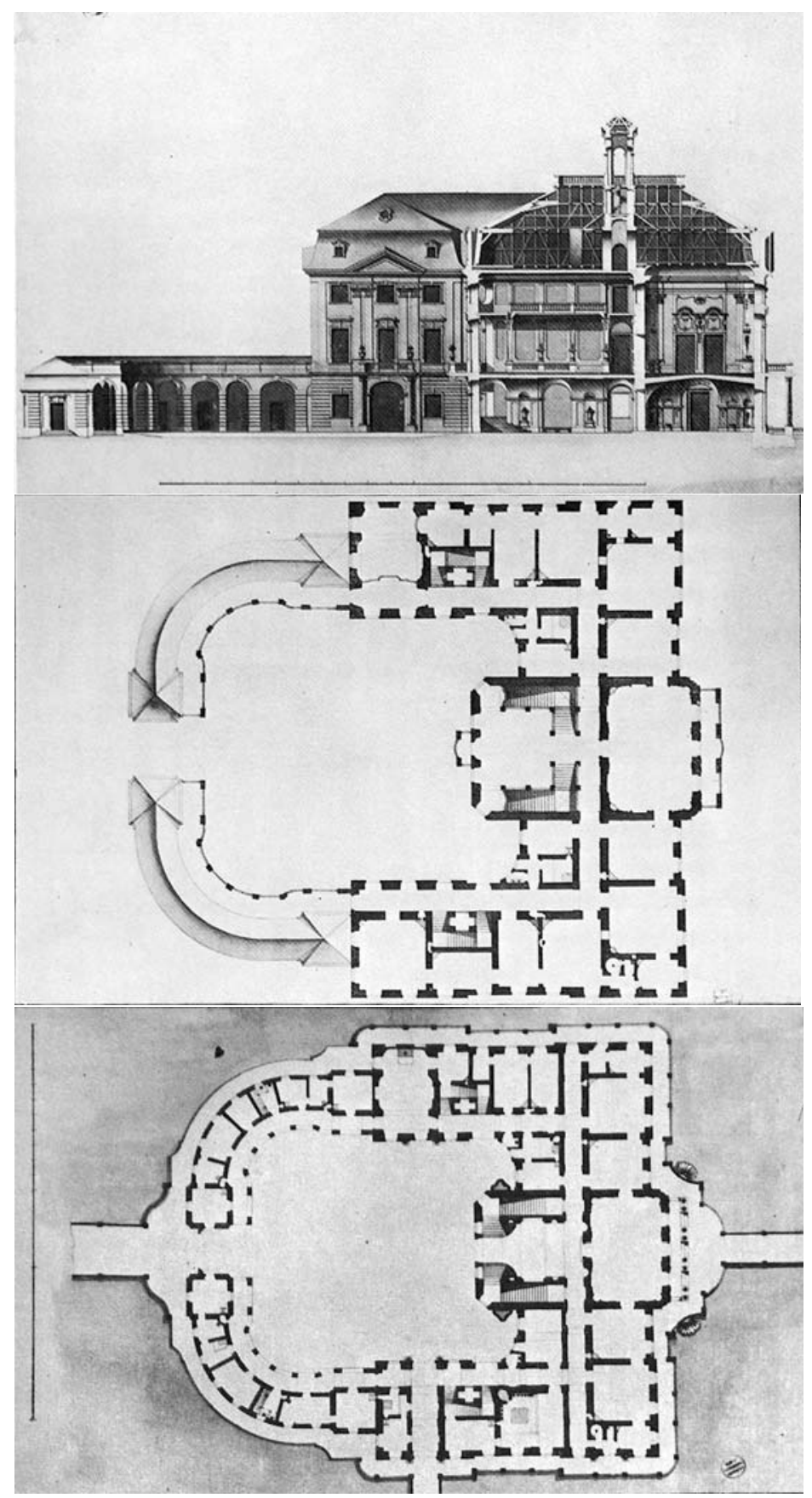

3. ábra. Külföldi „vízi kastély” alaprajzai és metszete 


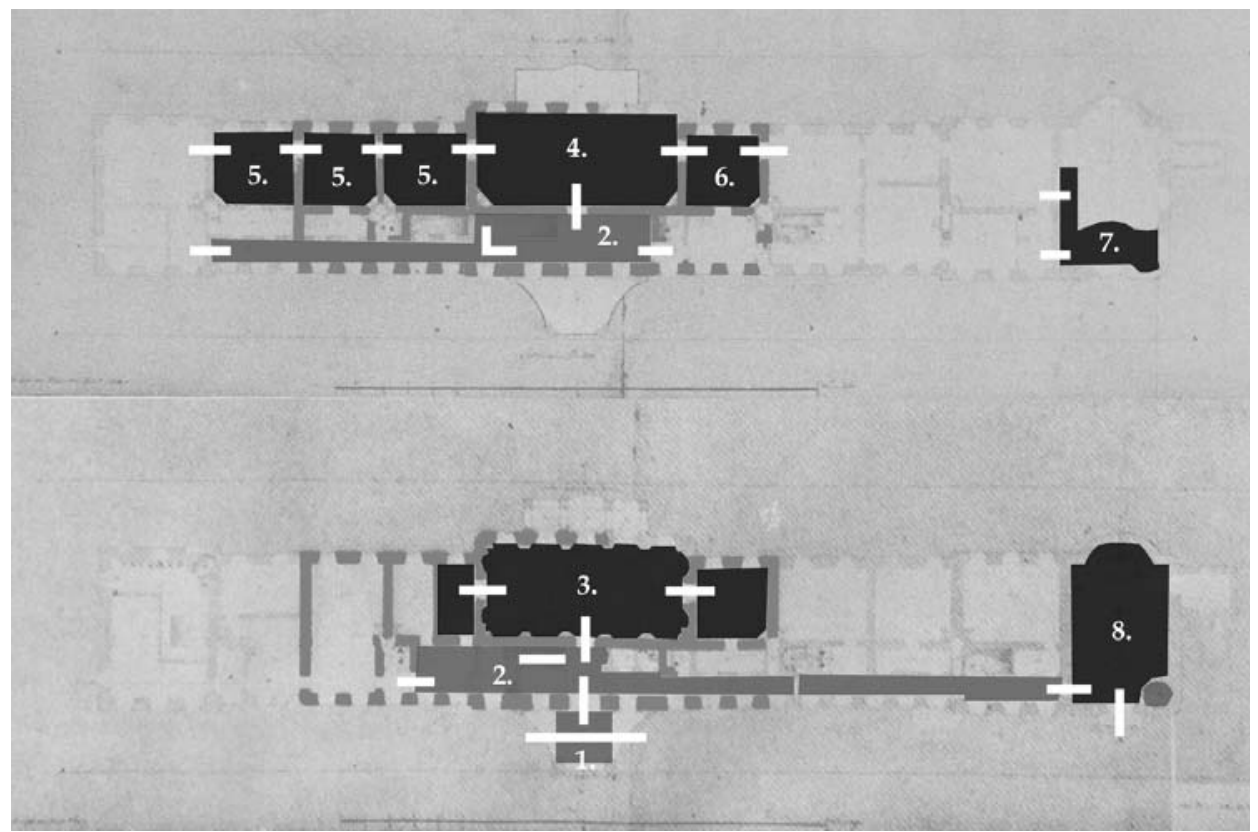

4. ábra. F. A. Hillebrandt, a gyulai kastély alaprajzai, 1760 (elemzés F. Cs.)

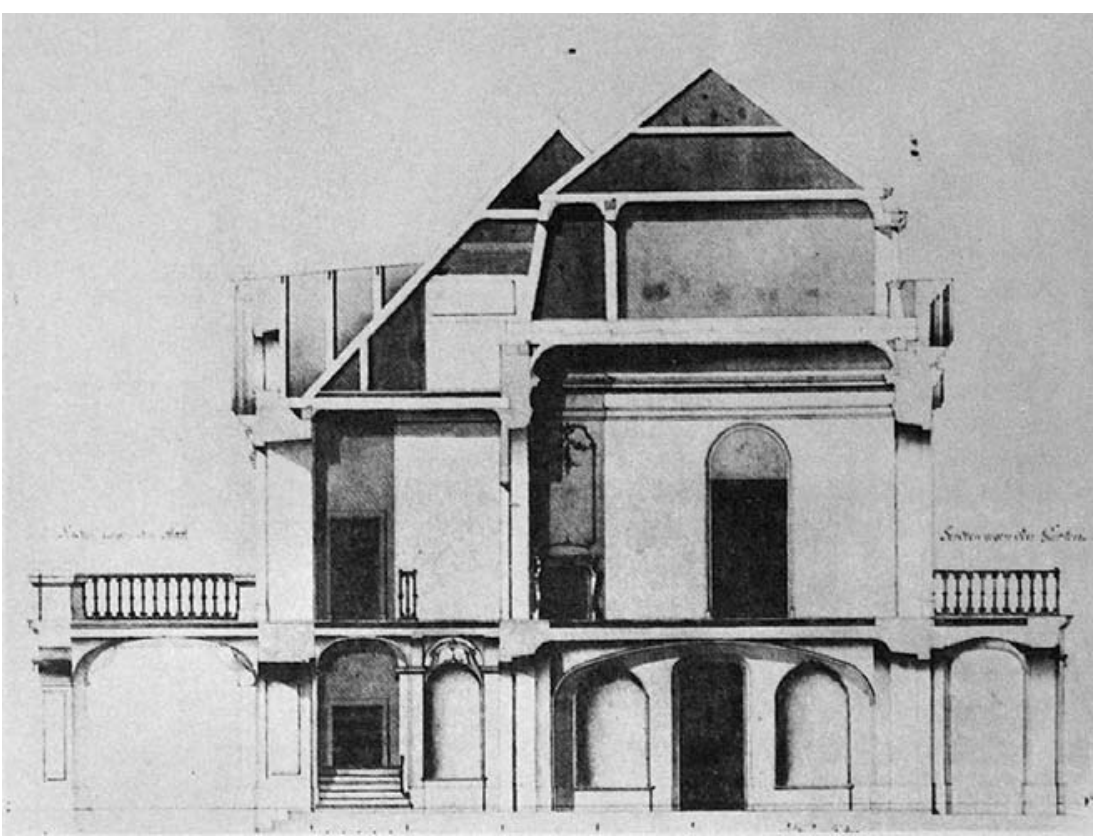

5. ábra. F. A. Hillebrandt, a gyulai kastély keresztmetszete, 1760 
tély középaxisában, az udvar és a tó felől a teljes rizalitot elfoglaló két előcsarnok tárja fel az épületet. Előbbihez kocsifelhajtó kapcsolódik terasszal (1), melyből három széles bejárati nyílás vezet az első előcsarnokba (2). Itt egy szimmetrikus elrendezésủ, törtkarú lépcső vezet az alagsorral kiemelt földszint második, tó felőli előterébe. Ez a sala terrena (3) szintén előcsarnok szerepű, nyugati oldalához a rizalit mellett kapcsolódik az emeleti galériás nagyterem előtti előszobába felvezető fôlépcső csarnoka (4). A középrizalit kettős előcsarnokához mindkét oldalon több nappali (6-8) és egy-egy hálószobát magábafoglaló lakosztályok kapcsolódnak, melyeket a tóra tájolt széles homlokzati loggia is összefog. Az udvari oldalon közösségi terek enfilade térsora húzódik.

Az ún. I. tervvariáns léptékében szerényebb, de lényegében azonos térszerkezettel készült. A kompozíció itt is a kocsifelhajtó (1) - lépcsőház-csarnok (2) - sala terrena (3) térsorral tárja fel az épületet, melynek földszintjére és emeletére egyaránt lakosztályok kerültek nappali (4-7) és hálószobákkal. A két épületszint itt egyenrangú, a földszint lakosztályai a melléklépcsőházak előterei (8), valamint az épülettengelyben lévő sala terrena révén nemcsak a tó látványának vizuális kapcsolatával, hanem közvetlen kertkapcsolattal is rendelkeznek.

Fellner Jakab tatai tervsorozata hagyományos barokk térelemeket (sala terrena, lépcsőház-csarnok) korszerü - francia rendszerü - kompozícióba foglaló tervei a megbízó, Esterházy Miklós gróf 1764. évi váratlan halála miatt nem valósultak meg. Az I. tervvariáns térkompozíciójának előremutató volta abban áll, hogy a két szint funkcionálisan azonos jellegű kialakításával és a földszint kertkapcsolatával utóbbi jelentősége, mind a közösségi, mind a lakóterek szempontjából megnö-

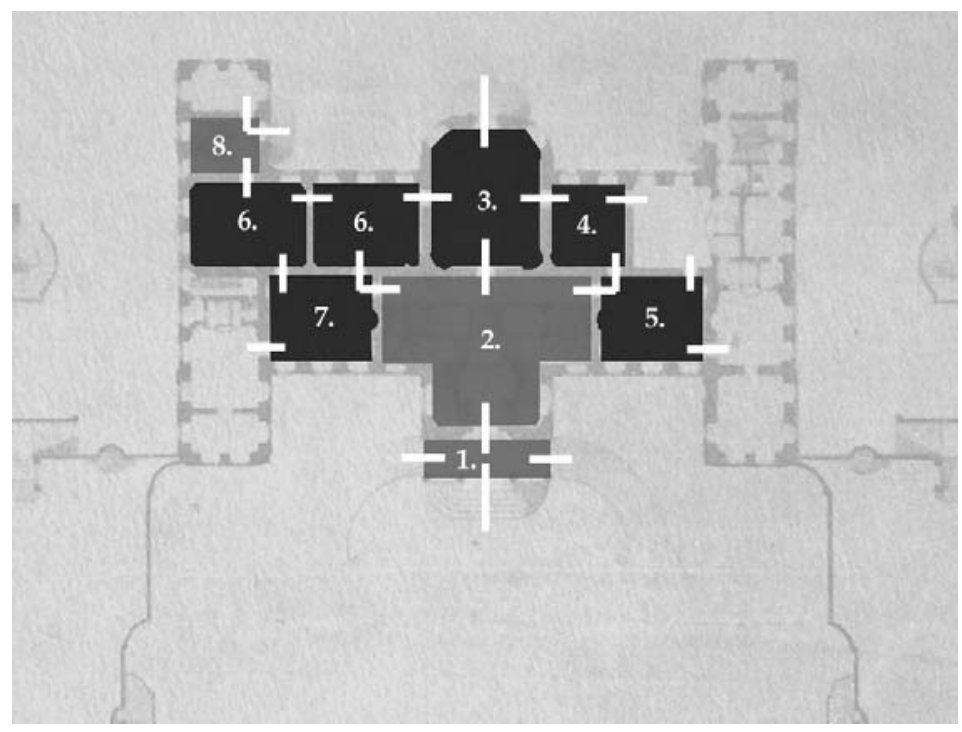

6. ábra. Tata, Fellner Jakab ún. I. tervvariánsa (elemzés F. Cs.) 

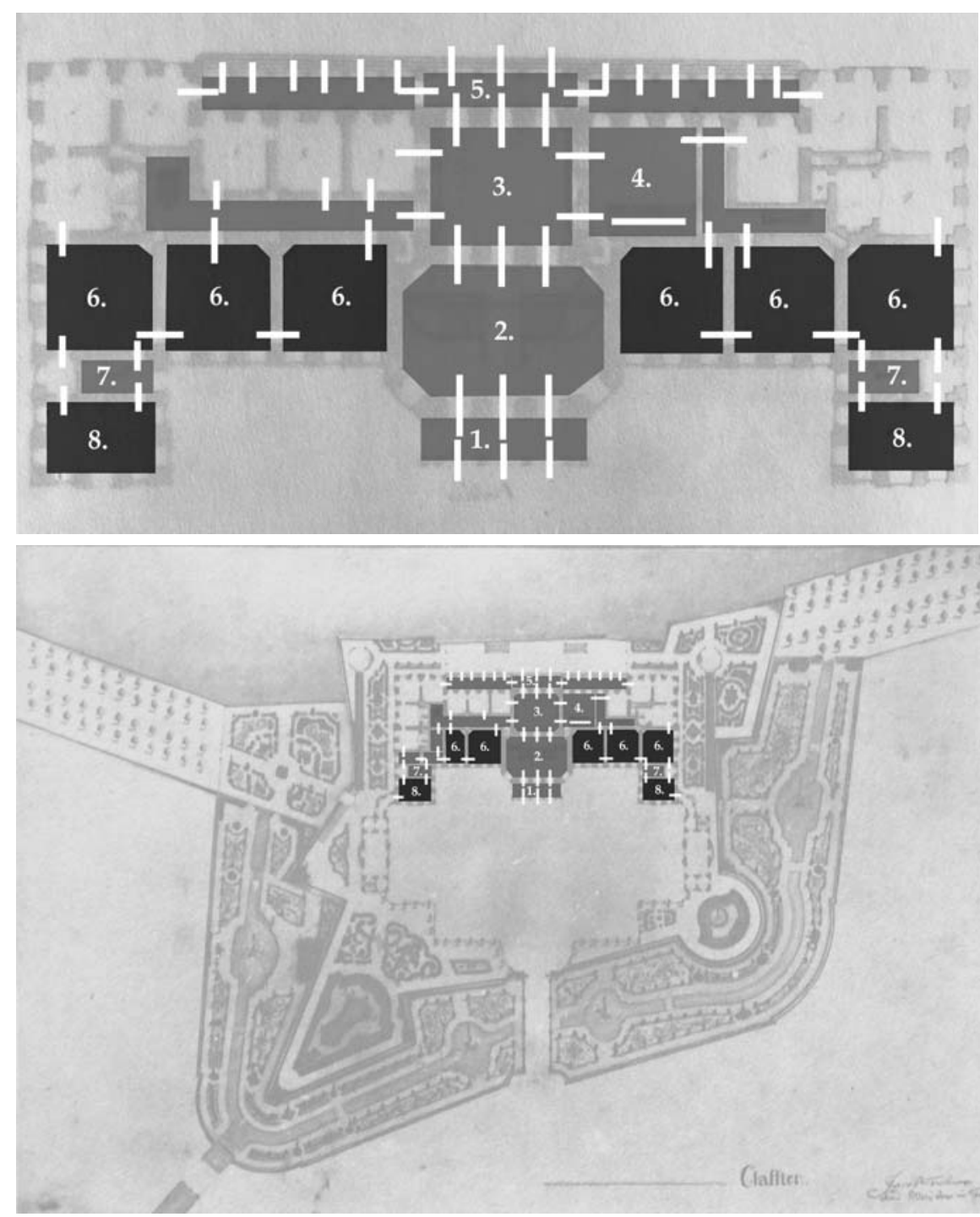

7. ábra. Tata, Fellner Jakab II., IV. tervvariánsa (elemzés F. Cs.)

vekedhetett. Lamberg Ferenc Antal (†1790) gróf 1762-65-ben, Fellner tervei szerint építtetett új móri kastélyának ${ }^{24}$ térszerkezetében ez a kompozíciós azonosság jól felismerhetó.

${ }^{24}$ Entz-Sisa 1998. pp. 106-107. 32. ábra. 


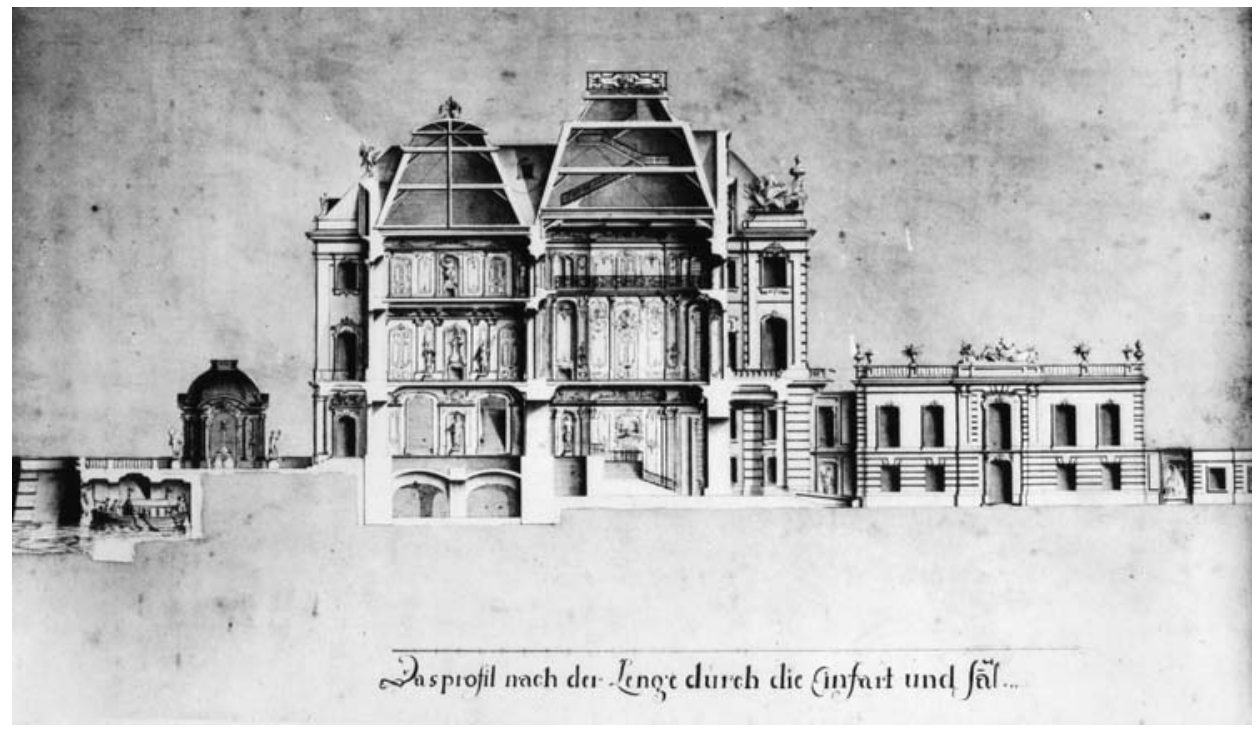

8. ábra. Tata, Fellner Jakab VI. tervvariáns keresztmetszete

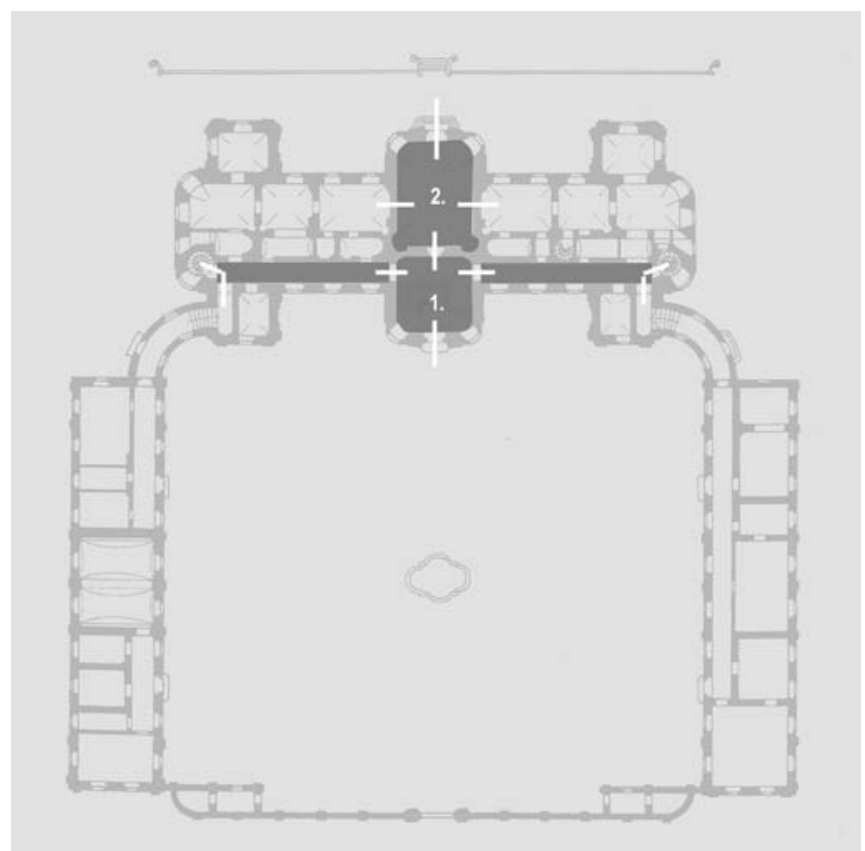

9. ábra. Mór, a kastély mai földszinti alaprajza (elemzés F. Cs.) 
A főbejárat Móron is a díszudvarról nyílik, s szintén lépcsőházcsarnokba (1) vezet. A lépcsőház szerényebb mérete, a lépcsőkarok aszimmetrikus vezetése szembetűnő különbség a fenti tervtől. A kastély középtengelyében e csarnokból sala terrena (2) nyílik, mely közvetlen kijárattal a díszkertbe vezet. A földszinti nagyterem két oldalán egy-egy lakosztály volt, s e terem ezek méltó előterét adhatta. Korabeli rendeltetése talán nyári ebédlő, vagy fogadóterem lehetett.

F. A. Pilgram nyomán és Fellner Jakab tevékenysége révén a francia rendszerü előudvaros kastélyok hazánkban az 1760-70-es években szélesebb körben terjedtek el. Ezt példázza báró Szepessy Sámuel 1775-79 között felépített noszvaji kastélya is, amelyet Povolni János építőmesternek tulajdonítanak. ${ }^{25}$
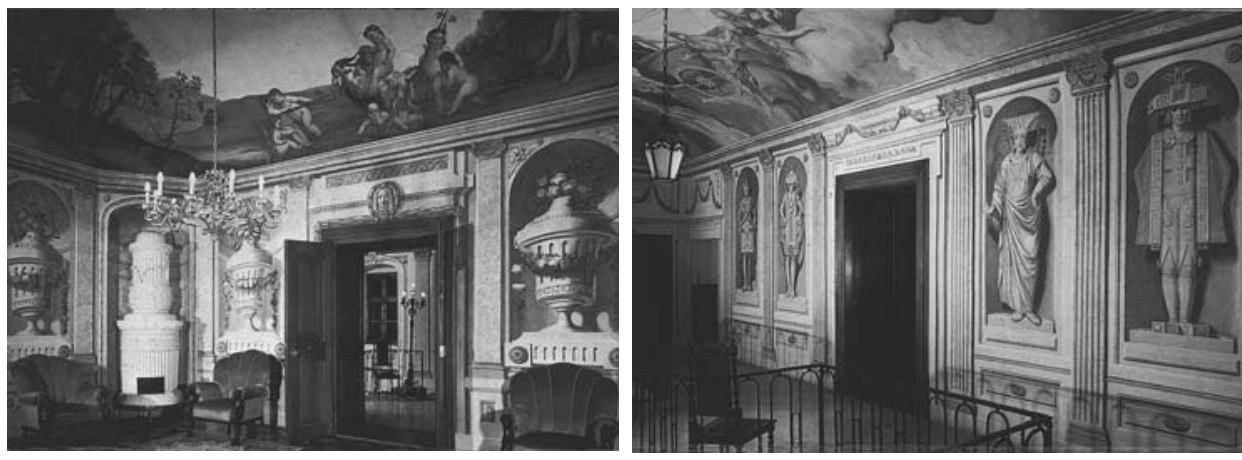

1
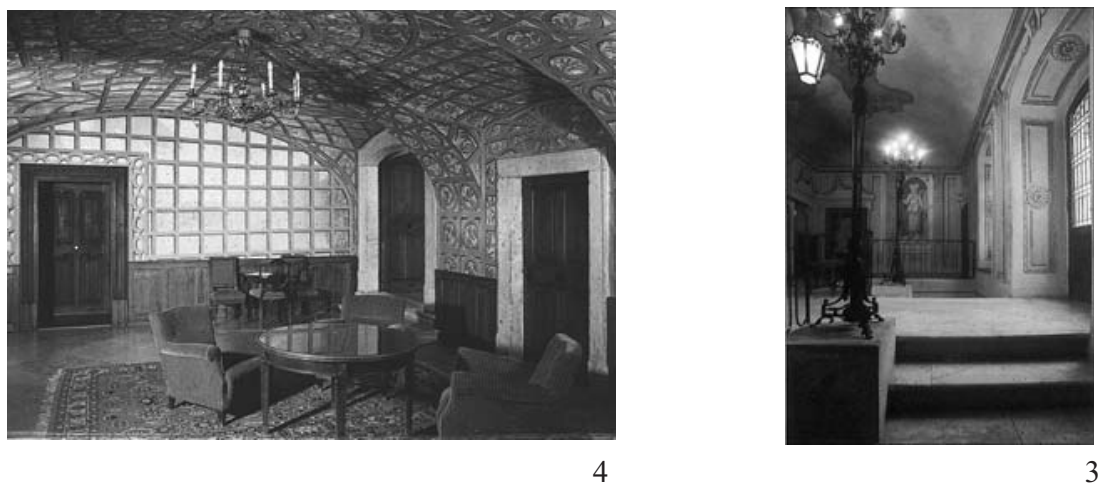

1-4. kép. Noszvaj, volt báró Szepessy Sámuel Louis XVI. stílusú kastélya, 1778-80. nagyterem (1), előcsarnok (2), lépcső (3), sala terrena (4)

(Ráfael Csaba felvételei. Képes levelezőlapok, MTI fotó. Révai kiadása, Eger, é. n.)

${ }^{25}$ Voit 1978. p. 471. 


\title{
A LAKÓ ÉS KÖZÖSSÉGI TÉRSOROK FÖLDSZINTI ELHELYEZÉSE AZ 1770-ES ÉVEKTŐL
}

A hagyományos barokk térszerkezet 1750-től kimutatható átalakulásának első állomásaként, az előudvaros diszpozíciók elterjedésével tehát megszünt a fóépületbe történő zárt (fedett) megérkezést biztosító kocsibehajtás, így feleslegessé vált a korábbi földszinti kocsibehajtó(csarnok). Mivel a kitüntetett szerepü tulajdonosi női és vendég szint továbbra is az emelet volt, csak a lépcsőház(csarnok) ôrizte meg hangsúlyos szerepét, amely ezért az épület főtengelyébe került. A vendégfogadás ebben, illetve a hozzákapcsolódó új földszinti nagyteremben (sala terrena) történhetett, így utóbbi fokozatosan reprezentatív jelleget öltő, földszinti lakrészeket feltáró előcsarnokká alakult át.

A kastély-térszerkezet fent vázolt, a XVIII. század utolsó harmadában lezajlott átalakulásának korszerúsödésének betetőzője gróf Esterházy János (1747-1800) csákvári kastélyának 1778-81-ben felépült bővítése lehetett. A terveket Fellner Jakab készítette el, azonban rajzai nem maradtak fenn, alapterve Gött Antal uradalmi építész 1798-as másolataiból ismertek. ${ }^{26}$

\begin{abstract}
A kastély fó, társasági és tulajdonosi lakosztályokat befogadó szintje a földszint. Ehhez az udvarról kocsifelhajtó (1) vezet, amely fölött négy oszlopon nyugvó terasz húzódik. A főbejárat az épület axisában az előcsarnokba (2) vezet, melynek folytatásában, a kerti oldalon a középső nagyterem, az ebédlő (3) terasszal bővítve helyezkedik el. Mindkét oldalához lakosztály kapcsolódik, jobbra a férfi (4), balra a női társalgó (5) és hálószobák következtek, melyekhez író-, és öltöző-kabinetek, ruhatár és zeneszoba kapcsolódtak. Az udvari homlokzat mögött folyosó húzódik, mely a kápolnát (8), illetve egy tágas termet (9) tárt fel az oldalszárnyakban. A lakosztályok és a folyosók között kisebb helyiségekből (kávékonyha, ruhatárak, komornaszoba) álló kiszolgáló zóna húzódott. Ebben kapott helyet, az előcsarnok bal oldalán a mezzaninemeletre vezető lépcsőház (6) is. A felső szinten, az előcsarnok fölött a biliárdszoba (7), a kerti traktusban a gyermekek és a nevelők nappali és hálószobái voltak.
\end{abstract}

A barokk térszerkezet hierarchikus viszonyai tehát az 1750-60-as években módosultak, majd az 1770-1780-as években felbomlottak. A fejlődés második állomásaként, az 1780-as években meghatározó funkcionális átalakulás zajlott le hazánk fóuri kastélytereiben. A nemenként tagozott tulajdonosi szint a földszintre került, ${ }^{27}$ így az emeletre vezető lépcsőház elveszítette fő forgalmi szerepét, ezzel összefüggésben hangsúlyos, térkompozíciós szerepét, s a középrizalit mellé, vagy

${ }^{26}$ MOL T20 No. 86. Közli: Sisa 1997. pp. 2-3. 3-4. kép

${ }^{27}$ Nagyobb méretü barokk rezidencia - nem pedig mulató-kastély (maison de plaisance) földszinti tulajdonosi szinttel feltünően kevés épült a XVIII. század első felében. Szinte társtalanul áll 


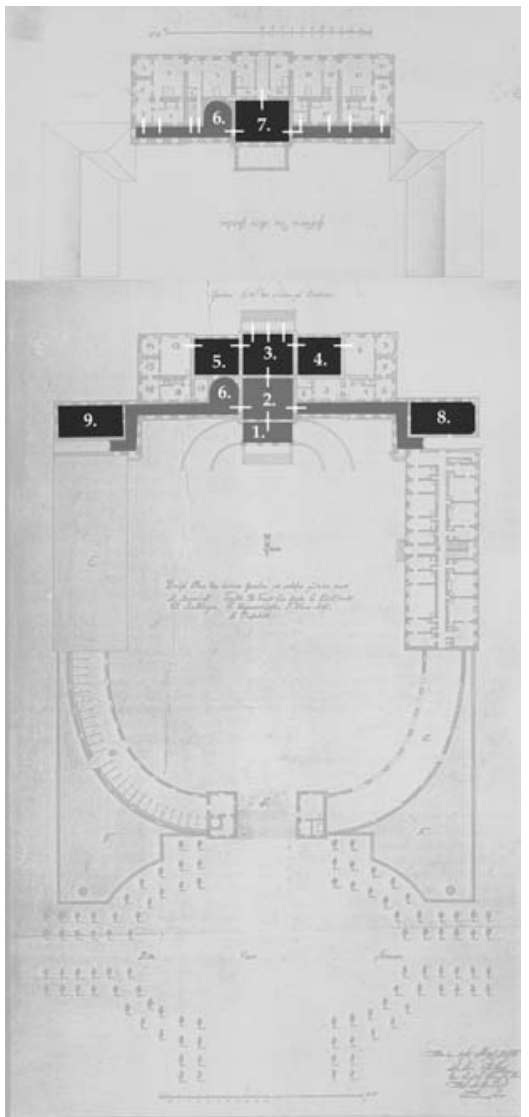

10. ábra. Csákvár, a kastély földszinti (lent) és mezzanin (fent) alaprajza

Aloys Thomas Raimund Harrach (1669-1742) gróf 1701-11 között Hildebrandt tervei szerint felépített (majd 1765-67 között F. A. Hillebrandt tervei szerint átalakított) féltoronyi kastélya; valamint F. A. Pilgram tervei nyomán 1731 után felépült tallósi [ma Toma'ikovo, SK] Esterházy-kastély. Mindkét, három rizalittal tagolt épület földszintje a tulajdonosi szint, s mindkét kastély axisát, a lakosztályok között egy előcsarnok és nagyterem együttese foglalja el. Féltorony középfolyosóval, Tallós udvari oldalfolyosóval tárja fel a már említett lakosztályokat, s a mezzaninemeletre vezető, hangsúlytalan elhelyezkedésü lépcsőt. (Alaprajzaikat közli Rados 1931. p. 218. 218. ábra; Jávor 1995. p. 204. 19. ábra.) Hasonló elrendezésű özv. gróf Széchényi Zsigmondné, gróf Cziráky Mária (1724-1787) (sopron)horpácsi kastélya 1773 körülről, gróf Brunszwick József (1750-1827) (alsó)korompai [ma Dolná Krupá, SK] 1793-94-ben épített, s 1820-28-ban átalakított kastélya; vagy Batthyány-Strattmann Fülöp (1781-1870) herceg 1805 és 1820 közötti bólyi kastélya is. E a tömör elrendezés és zárt kompozíció korszerúségét mutatja, hogy a XIX. század 30-as éveinek végéig kisebb-nagyobb léptékü klasszicista változatokban is továbbél. Például gróf Zichy VI. János (1777-1830) tervezett ó-szőnyi [ma Komárom] földszintes kastélya Pollack Mihálytól (1773-1855) 
az oldalszárnyak valamelyikébe került át. A kastély középtengelyében a vendégfogadás új tércsoportja alakulhatott ki a főbejáratból feltáruló előcsarnok és a mögé helyezett nagyterem (sala terrena) együttesében. Ez utóbbi ekkor már a lakóterek sorába integrálódott, leggyakrabban közvetlen kertkapcsolattal rendelkező ebédlő - esetleg más társasági (pl. biliárd) - rendeltetéssel. Két oldalához a nemenként elkülönülő lakosztályok nappali és hálószobái kapcsolódtak, hagyományos barokk enfilade térfüzéssel.

A XVIII. századvégi térkompozíciós fejlődés és funkcionális átalakulás eredményeképpen létrejövő földszinti társasági és tulajdonosi lakószint tengelyének építészeti hangsúlya továbbélt a XIX. század első negyedében is. A kastélyok középtengelyét elfoglaló, a nemek szerint tagozódó lakosztályok közötti nagyterem ebédlő rendeltetése volt ekkor a leggyakoribb, s szinte kivétel nélküli közvetlen kertkapcsolatát egy divatos építészeti elem, a portikusz biztosította. Az épület föbejárata azonban nem itt, hanem a túlsó, díszudvar felőli oldalon, kisebb előcsarnokba nyílt.

Ezt a „klasszicista” térkompozíciót mutatja a kor meghatározó épülete, az alcsúti kastély. ${ }^{28}$ A kastélyt József nádor (1796-1847) építtette Pollack Mihály (1773-1855) tervei alapján, 1819-1826 között. ${ }^{29}$ Szúkszavú, korabeli leírása Novák Dániel architectustól, 1836-ból maradt fenn, ${ }^{30}$ valamint 1920 -as évekbeli alaprajza ismert.

A kastély fố társasági és lakószintje a földszinten helyezkedett el. Főbejárata a három épületszárny által közrefogott második díszudvarról nyílt, s kisebb előcsarnokba (1) vezetett. A kastély középtengelyét, a kert felé később ebédlőnek használt nagyterem (2) foglalta el, melynek két oldalán enfilade-térfüzéssel a nádori (4) és hercegnői (5) lakosztályok nappali szobái kapcsolódtak, a férfi oldalon a fegyverteremmel és a képtárral, a női oldalon két társalkodó szalonnal. Ezeket egy-egy dolgozó-, majd hálószoba követte. Az alacsonyabb belmagasságú mezzaninemeletet a család többi tagjának és a vendégeknek fenntartott lakosztályok foglalták el. Ide az előcsarnokból nyíló csarnok (6) háromkarú lépcsője vezetett fel.

Az 1800-as évek eleji építkezésekben (például gróf Cziráky Antal Mózes (1772-1852) 1804-től Lovasberényben Rieder Jakab tervei szerint, vagy Szegedy IV. Ferenc (†1848) 1824-ben Acsádon) e típus sajátos változataként terjedt el az

1815-ben; vagy gróf Teleki V. Sámuel (1792-1857) Hild József (1789-1867) tervei alapján 1835-41-ben felépült mezzaninszintes gyömrői kastélya. (Alaprajzaikat közli: Rados 1939. p. 67.; Kelényi 1974. p. 21.)

28 Alaprajzát közli: Rados 1931. p. 229. 230. ábra.

${ }^{29}$ Soós 2002. p. 23.

30 Novák 1836. pp. 231, 235. 


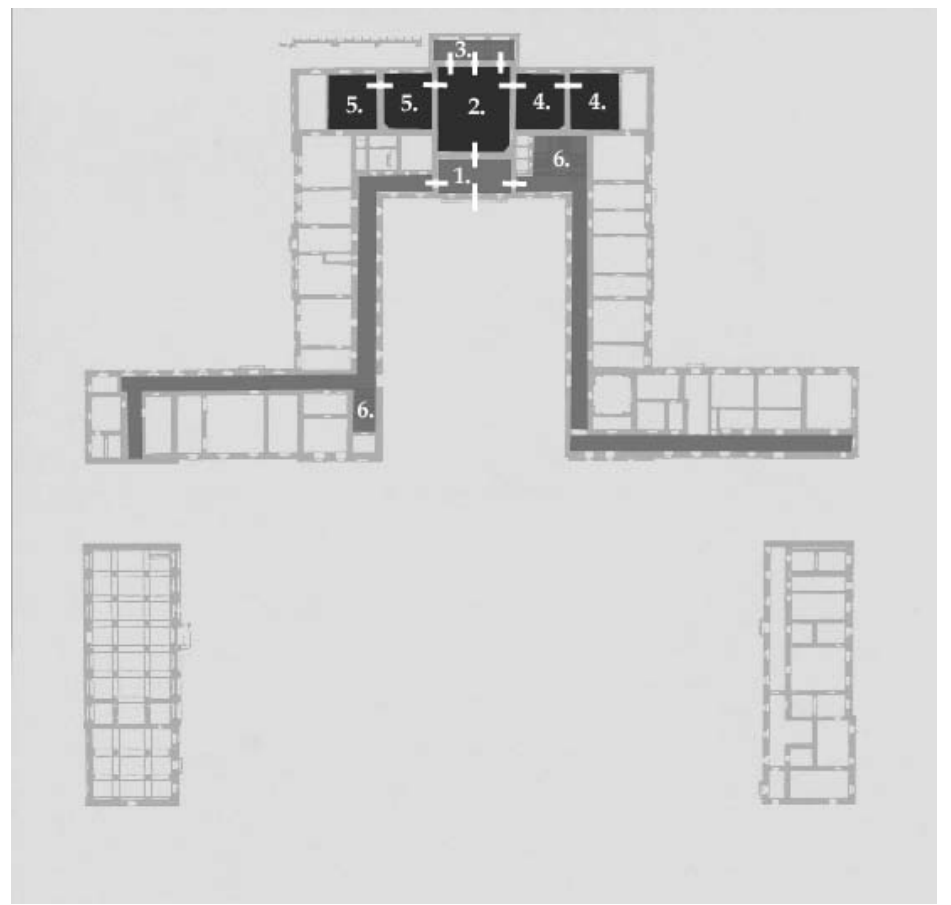

11. ábra. Alcsút, kastély földszintjének első periódusa (rekostrukció és elemzés F. Cs.)

oldalsó kocsiáthajtós feltárás, mely az épületbe ismét behajtva biztosított zárt megközelítési lehetőséget anélkül, hogy a fóépület axisának reprezentatív vendégfogadó tércsoportját (előcsarnok, nagyterem) érintette volna. A kocsiáthajtó általában a fő lakószárny és a kiszolgáló oldalszárny találkozásánál nyílt, s mindkét épületszárnnyal folyosó közbeiktatásával állt kapcsolatban. Praktikusan itt vagy ennek közelében helyezkedett el a mezzaninemeletre vezető - építészetileg kompozíciós szerepét és hangsúlyát vesztett - lépcső is. E megoldás későbbi példái (gróf Károlyi István (1797-1881) kastélya Fóton, Heinrich Koch, 1832-36; vagy gróf Sándor Móric (1805-1878) kastélya Bajnán, Hild József, 1834 és 1842 között) az 1830-as évek kastélyátalakításaiban maradtak fenn.

A seregélyesi kastélyt gróf Zichy Ferenc (1774-1861) építtette fel 1821-22ben, a hagyomány szerint I. Ferenc király (1792-1830) vendégül látására. Korabeli források híján az épületet stíluskritikai alapon Pollack Mihálynak (1773-1855) tulajdonítják. ${ }^{31}$ Alaprajza az 1930-as évekből ismert. ${ }^{32}$

31 Örsi 1986. p. 203.

${ }^{32}$ Közli: Rados 1939. p. 65. 

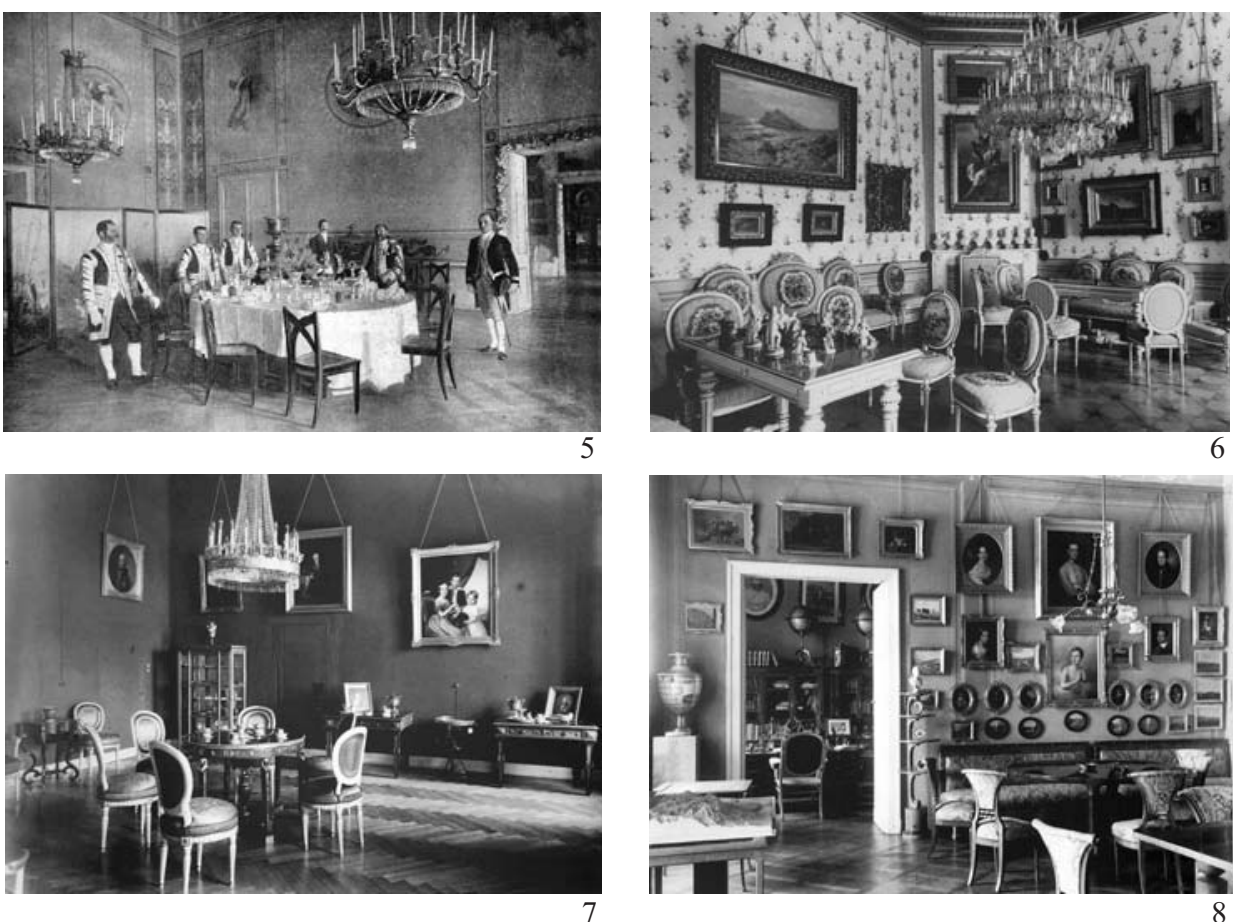

5-8. kép. Alcsút, a kastély társasági terei 1900 körül ebédlő nagyterem (5), első (6) és második női szalon (7), képes szoba (8) (Soós 2002. 28, 30-31, 36.)

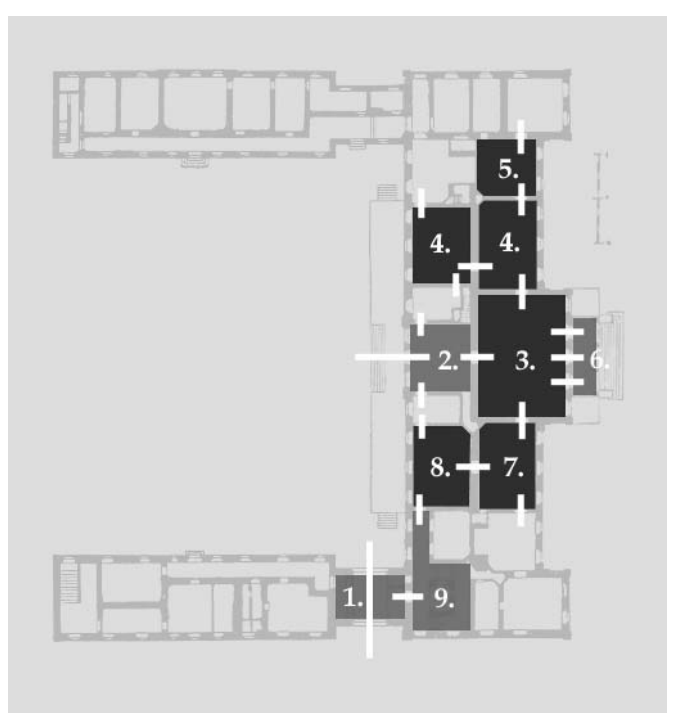

12. ábra. Seregélyes, kastély földszinti alaprajz (elemzés F. Cs.) 

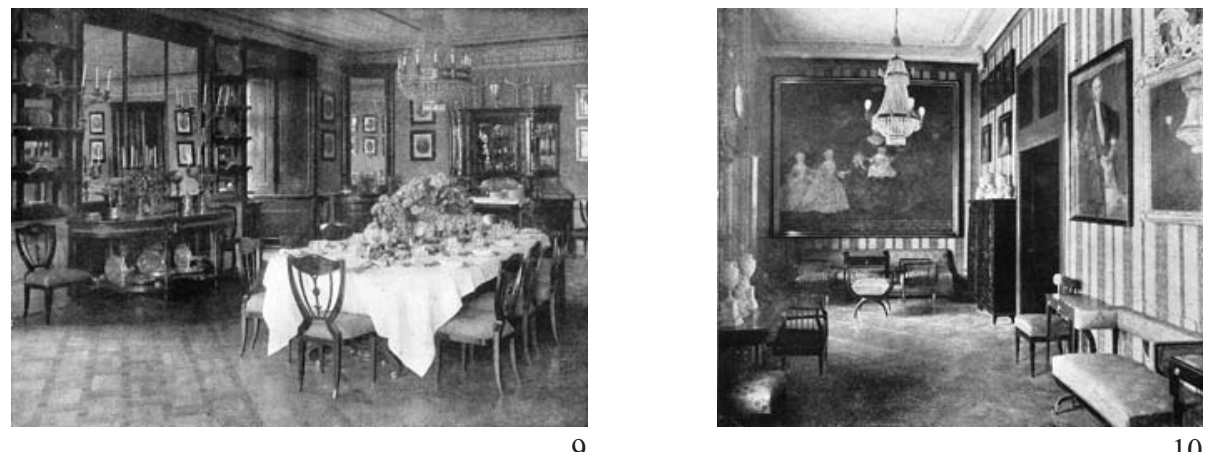

10
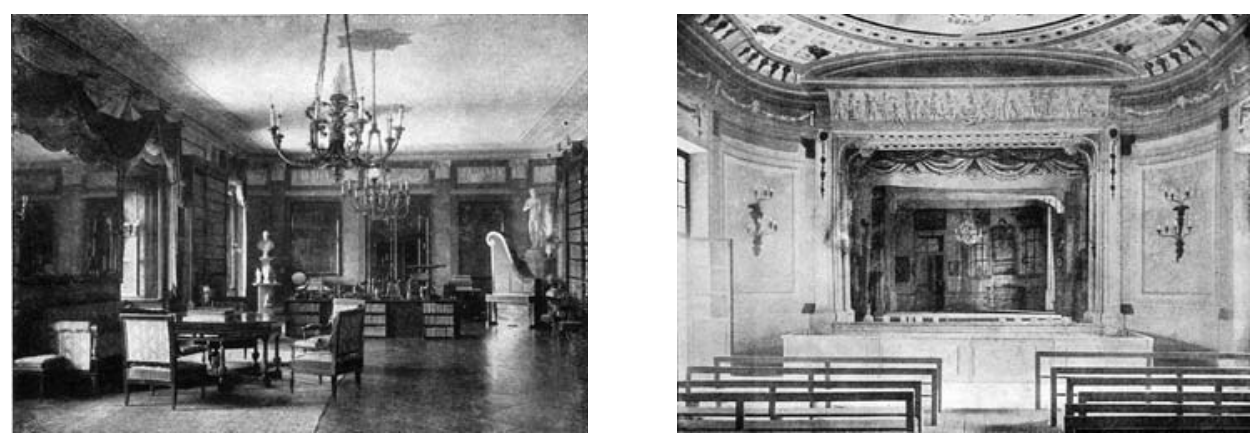

11

9-12. kép. Galgóc, kastély 1800 körüli empire termei ebédlö (9), kisszalon (10), könyvtár (11), színház (12)

(Voit 1943. 281-285.)

A kastélyban - építési céljának megfelelően - a királyi vendéglakosztály, a közösségi terek, valamint a tulajdonosi lakosztály egy szinten, a földszinten helyezkedett el. A fóépület-szárny és az északi oldalszárny közötti kocsiáthajtó (1) vezetett az udvarra, ahol az épület főaxisában előcsarnok (2) nyílt, mögötte a kert felé nagyteremmel (3). A kerti homlokzat axisát portikusz hangsúlyozza (6). A lakosztályok nappali szobái $(4,5,7,8)$ e nagyterem két oldalához enfilade-rendszerben kapcsolódtak, dél felől a császári lakosztály fogadótermével (4). A mezzaninemeletre vezető lépcsőház (9) ezekkel egy kis folyosó révén állt kapcsolatban, de a kocsiáthajtóból közvetlenül volt megközelíthetö. ${ }^{33}$

A XIX. század első negyedének korszerű kastélyterei ${ }^{34}$ már csak középhangsúlyukban, a lakosztályok középszimmetriára törekvő telepítésében és enfilade térfüzésében őriztek korábbi hagyományokat. A barokk hierarchikus alá-fölérendelt-

33 Wolf 1988. pp. 96-104.

34 A korabeli berendezésre jó példát mutatnak gróf Erdődy Ferenc (1830-1906) és Oberndorff Ilona (1831-1932) grófnő galgóci [ma Hlohovec, SK] kastélyának empire stílusú társasági terei. 
ségi viszonyok felbomlásával fokozatosan új térkompozíciós lehetőségek tárultak fel. Ennek kihasználása viszont már az 1790-es évek legvégétől kimutatható.

\section{A LAKÓ ÉS KÖZÖSSÉGI TÉRSOROK MELLÉRENDELT HELYZETƯ, SOROLT DISZPONÁLÁSA 1790 ÉS 1840 KÖZÖTT}

Gróf Batthyány Tivadar (1729-1812) bicskei kastélyának 1796-99 közötti, valószínűsíthetően Hild János (1766-1811) tervezői közreműködésével történt kiépítésekor létrejött U-alaprajzú épület ${ }^{35}$ funkcionális tagolása és térszerkezete egyaránt újszerủ a korszakban.

A kastély átalakítás előtti alaprajza valamint a bővítés után létrejött épület 1920-as évekbeli alaprajzai is ismertek. ${ }^{36}$

Az északkeleti szárny földszintje, az átalakítás előtti állapotban egyszerü egytraktusos-oldalfolyosós elrendezést mutat. A nyugat felől gazdasági épületekkel övezett udvarra kapu (1) nyílt. A bejárat az oldalfolyosóra, majd közvetlenül a lépcsőház terébe (2) vezetett. Mögötte kápolna (3) volt. A folyosó és a szobasor végén a traktust tágas nappali szoba (4) foglalhatta el.

Az átalakítás újszerüsége legmarkánsabban abban jelentkezett, hogy a kastély középaxisának hangsúlya elmaradt. Az új kocsibehajtó (1) is - szomszédságában a kápolnával (6) - az oldalra került tulajdonosi lakószárny mellett épült meg. A lakószárny külön bejárattal, a tengelyében nyíló kör alaprajzú teremmel $(2,7)$ tárul fel mindkét szinten, melyhez lépcsőház (3) kapcsolódik. A kör alaprajzú termek funkcionálisan a társasági rendeltetések $(5,8)$ részei, mivel az egyik oldalához a háló- és kiegészítő szobák csoportja, másik oldalához nappali termek, szalonok $(8,9)$ kapcsolódnak. Utóbbiak összeköttetésben állnak a másik épületszárny tánctermével (10) és ebédlőjével (11) is. A kör alaprajzú, illetve sarokszedett, vagy alkóvos terek individuálisan formáltak, ugyanakkor ún. könyöktengelyes enfilade-rendszerrel egy zárt, kívül tagolatlan tömbbé kapcsolódnak össze.

A dégi kastély 1815-19 között tolnai Festetics Antal (1764-1853) megbízásából felépített új épülete a korabeli térkompozíciók szintén újszerü változatát mutatja. Pollack Mihály eredeti tervei publikált fotóból ismertek, ${ }^{37}$ valamint fennmaradt 1859. évi inventáriuma is. ${ }^{38}$

35 Sisa 1994. pp. 65-70. (Sisa József tanulmányában a régi kastély befoglalásával létrejövő, nagyságrenddel megnövelt, reprezentatív rezidencián a barokk hagyomány jegyében, Széchenyi István szavaival kifogásolja, s minősíti kényszermegoldásnak az emeleti nagyterem oldalra helyezését, $\mathrm{s}$ a főlépcsőház ettől távoli diszponálását.)

${ }^{36}$ MOL T4 No 35. Közli: Sisa 1994. 67. p. 2. ábra; valamint Rados 1931. 226. p. 224. ábra.

${ }^{37}$ Rados 1931. p. 227. 225-226. ábra.

${ }^{38}$ SML XI. 602. 2. doboz. Közli: Sisa 2005. pp. 112-127. 

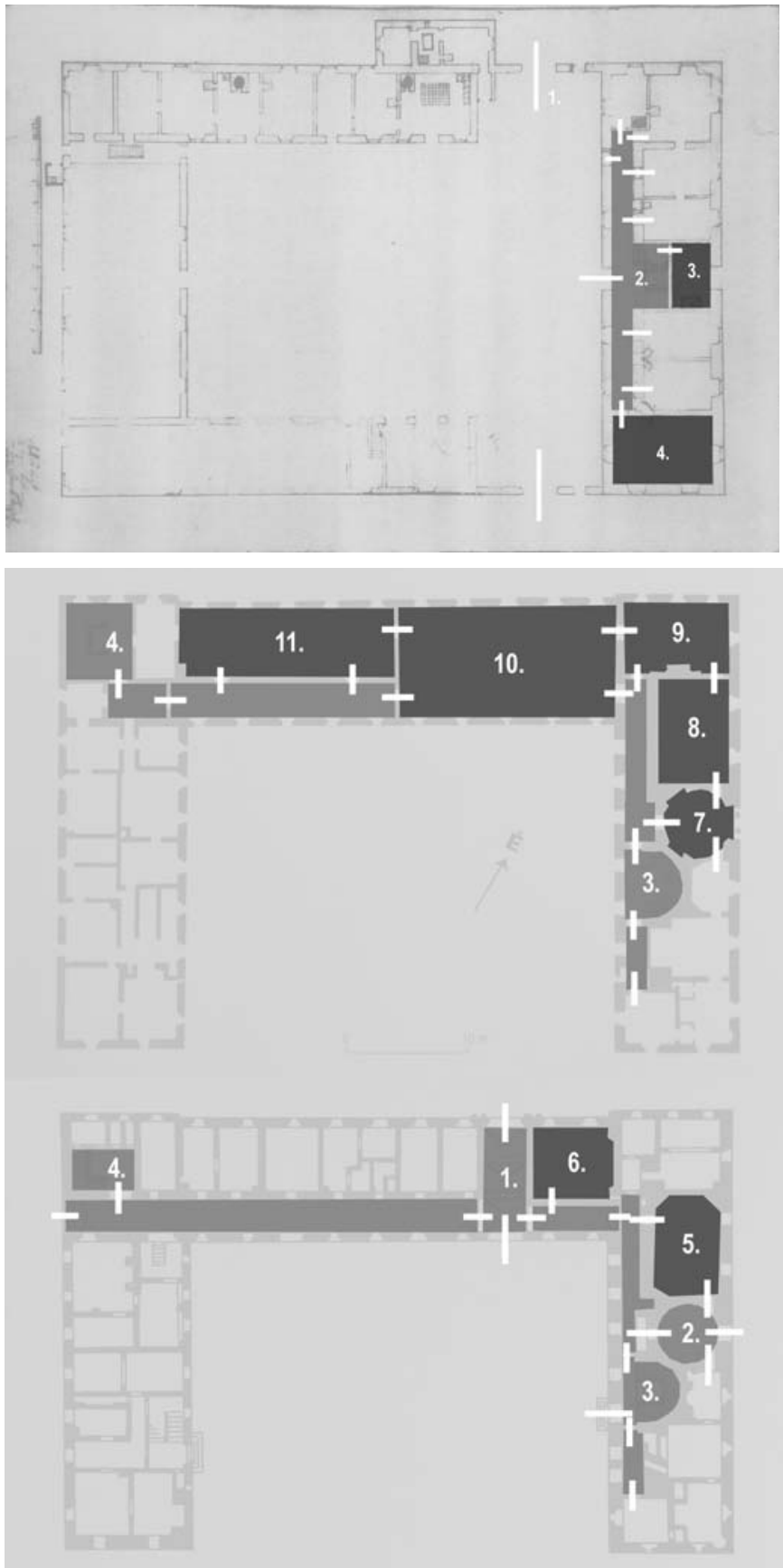

13. ábra. Bicske, kastély alaprajzai 1796 előtt (fent) és után (lent) (elemzés F. Cs.) 


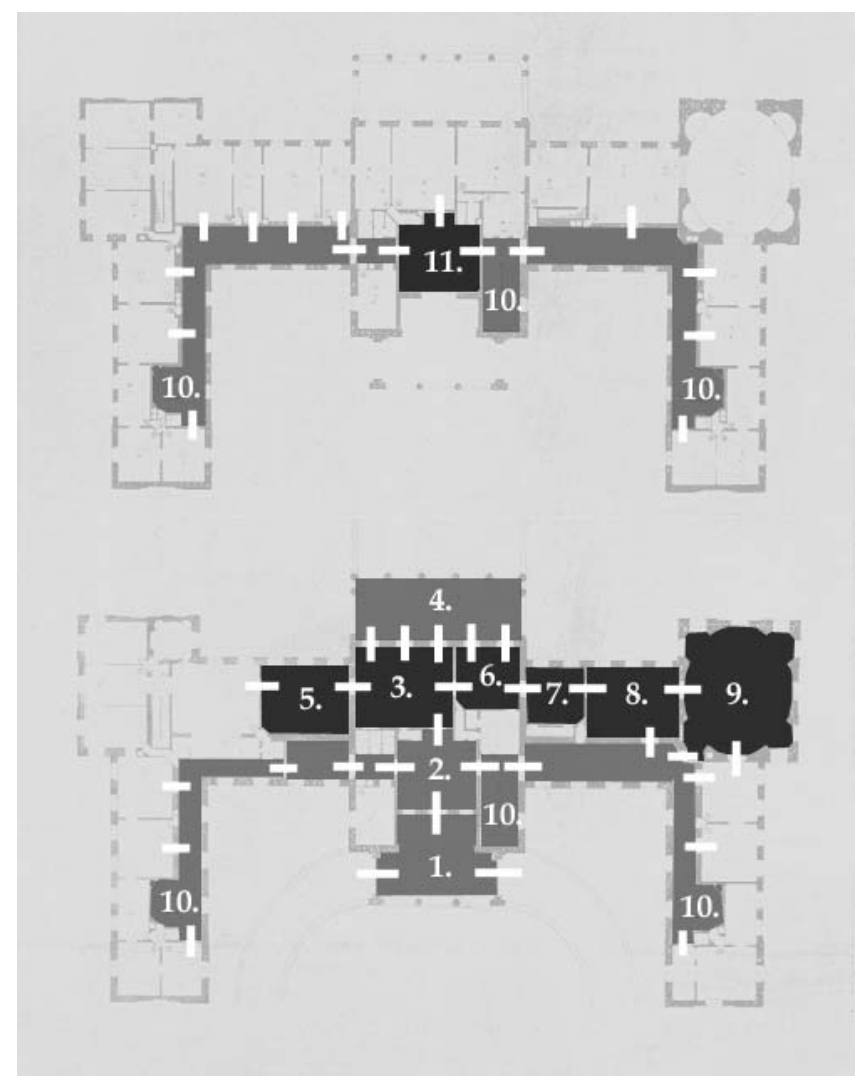

14. ábra. Dég, kastély földszinti (lent) és mezzanin (fent) alaprajza

A tömeg hagyományos három rizalitos tagolása, középhangsúlya, a földszint belső terének reprezentatív és korszerü kocsifelhajtó (1) és kapcsolódó előcsarnok (2) feltárása mellett a tulajdonosi társasági és lakórendeltetések elhelyezésében hoz újat. Az előcsarnokból axisban nyílt az ebédlő (3), mely teljes egészében nem töltötte ki a portikusszal (4) hangsúlyozott kerti középrizalitot. Az ebédlő csak az enfilade-rendszerű lakótérsor egyik közbenső, méretével, formálásával nem meghatározó eleme volt. Egy olyan mellérendelt funkciósor része, amely csak központi elhelyezkedése révén juthatott hangsúlyhoz, téralakítása erre nem reagált. A keleti szárny közös tulajdonosi hálószobájától a rendeltetéssor a kapcsolódó szalonon (5), ebédlőn (3), a két könyvtárszobán $(6,7)$ és a biliárdszobán $(8)$ keresztül vezetett a nyugati sarokrizalitban elhelyezett el a nagy táncteremig (9). Ennek sarokrizalitba foglalt, fülkékkel bővített, elliptikus alaprajza fölé emelt nagyvonalú tere szakított végleg a térsor barokk térszervezési és funkcionális hagyományaival. 
A bicskei és dégi kastélyok szakirodalomban ${ }^{39}$ egyaránt furcsállott funkcionális és építészeti megoldásai a XVIII-XIX. századforduló legjelentősebb hazai kompozíciós újításának is értékelhetők. Felnyitották az utat a tengelyre füzött terek újszerű, mérettel és alakkal differenciált egyedi formálásának lehetősége felé, melyben a rendeltetések mellérendelt viszonyában eleinte hosszirányú (lineáris) kompozíció révén valósulhatott meg a reprezentatív közösségi- és hozzá szervesen kapcsolódó lakótérsor.

A gyöngyösi kastély 1830 körüli bővítésekor, ifj. báró Orczy Lőrinc (17841847) megbízásából felépült új épületszárnyai ${ }^{40}$ e fejlődési vonal kiváló tükrözői. Zofahl Lőrincnek tulajdonított eredeti, 1826-ra datált (ti. évszám és szignó nélküli) tervrajzai fennmaradtak. ${ }^{41}$

A kastély kisszámú közösségi terei a földszinten és az emeleten megosztva, a lakosztályokhoz rendelve helyezkedtek el. A kapualjból (1) nyíló lépcsőház (2) és előszoba (Vorzimmer) (3) tárta fel az emeleti közösségi tereket. Az előszobát az ebédlőterem (Speize Saal) (4) - amely itt sem foglalta el az egész rizalitot - követte, mellette a biliárdszoba (Billiarde) (5) majd az elliptikus alaprajzú, fülkékkel bővített szalon (Salon) (6) a sarokrizalitban. (Innen haránttengelyben a közös tulajdonosi hálószoba írókabinettel, folytatásában ruhatárral volt megközelíthető.) A tulajdonosi lakosztály az udvari traktust is elfoglalta, mely a vendég- és cselédszobák felé kis előszobával volt átjárható. Az emeleti lakosztályt a földszinti alkóvos hálószobával egy csigalépcső közvetlenül kötötte össze. A földszinti férfi lakosztály a kapualjjal (1) egy előszoba (7) és egy fogadószoba (8) révén állt közvetlen kapcsolatban.

A historizmus korszakának kezdetén, 1750 körül a kastélyokban a korábbi feltárási mód megváltozása (előudvar elterjedése) tehát, nemcsak egy új földszinti térelemet (sala terrena) indukált, hanem a hagyományos lakó- és társasági rendeltetések differenciált kezelésének kialakulását is eredményezte.

A korabeli kastélyok emeletes lakrészeinek struktúrája funkciószervezés és téralakítás szempontjából 1770 és 1800 között mutatott újdonságot. Mind a földszinti, mind az emeleti lakó- és társasági rendeltetések rendszere elveszítette a szimmetriára törekvő, hierarchikus elrendezését és reprezentatív feltárását. A lakályosság új törekvésének jegyében kialakult a differenciált társasági és lakórendeltetések sora az emeleten és a földszinten egyaránt, melyben a lakosztály az előcsarnok révén különült el a közösségi rendeltetésektől. E változás következménye a téralakításban is jól tükröződik. Az épület feltárása axiális ugyan, a sala terrena köz-

\footnotetext{
39 A legjelentősebb XIX. századi hazai kastélyokat (Bicske, Dég, Nagyhörcsök, Mikosszéplak, Nádasdladány stb.) Sisa József művészettörténész kutatja.

40 Voit 1978. pp. 132-133.

41 Jelenleg a gyöngyösi Mátra Múzeumban találhatók. Közli: Voit 1978. pp. 134-135. 130131. ábra.
} 


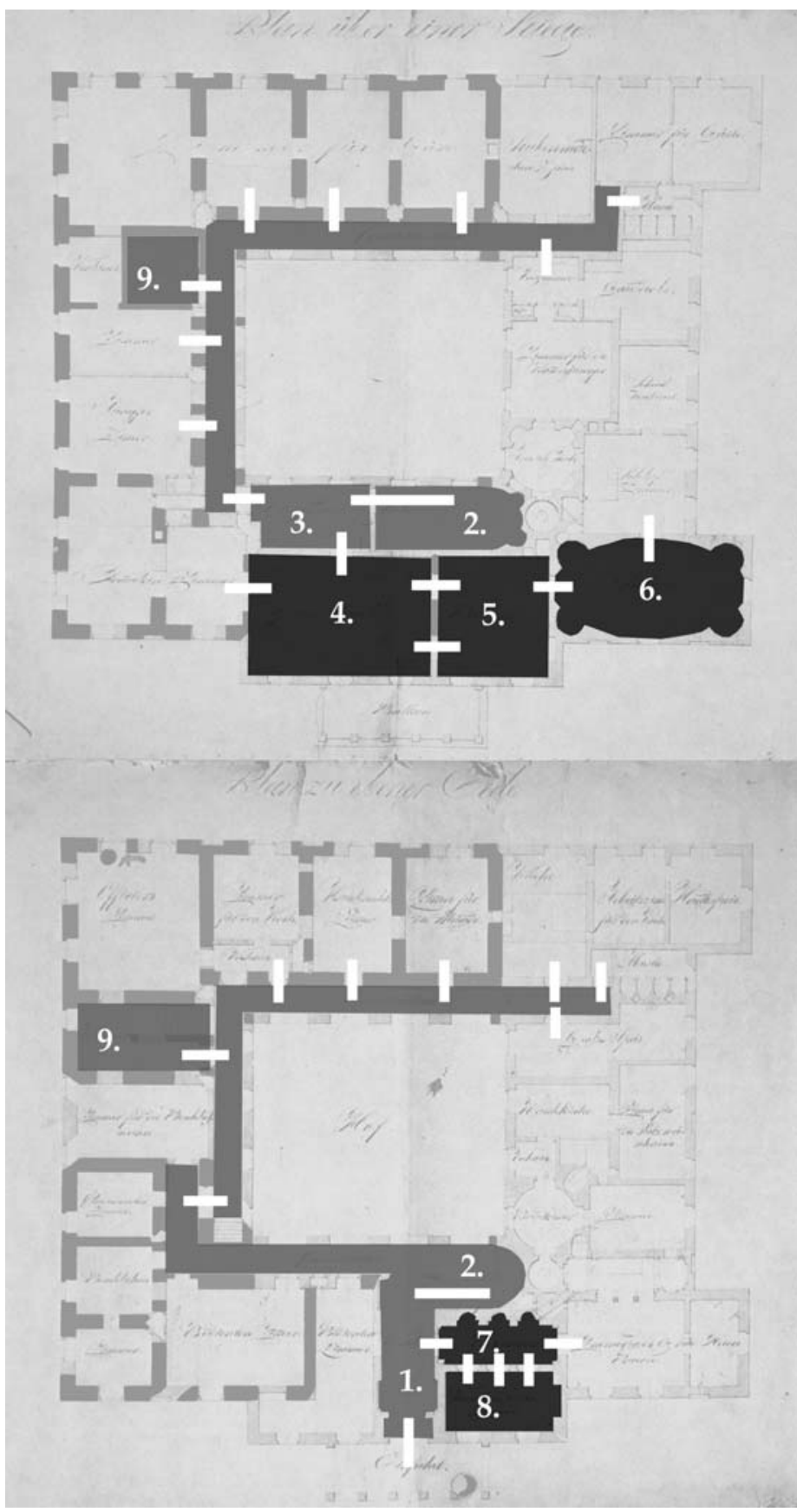

15. ábra. Gyöngyös, kastély földszinti (lent) és emeleti (fent) alaprajza (elemzés F. Cs.) 
ponti elhelyezkedésű, előcsarnok szerepü, az emeletre vezető lépcsőház azonban már aszimmetrikusan oldalra került, mellyel hangsúlyát veszítette. Jellemző, hogy a két oldal - az eltérő rendeltetés miatt - aszimmetrikussá vált. Egyik oldalon tulajdonosi lakosztály, a másikon társasági terek sora kapott helyet.

A kastélyok térkompozíciós újításai és funkciószervezési változásai között a tulajdonosi lakó és közösségi térsor földszinti elhelyezése 1780 után történt meg, majd e funkciók mellérendelt szerepü elrendezése az 1810-es évektől zajlott le. Ugyanakkor a kastélyok őriztek hagyományosnak tekinthető megoldást is, mely első sorban a forgalmi és közösségi rendeltetések hangsúlyos középtengelyben való elhelyezése és a lakórendeltetések előbbi két oldalára, közel szimmetrikusan - de a földszinten - történő diszponálása volt. A földszinti közösségi rendeltetések közül a középső ebédlő az 1820-as évekig volt meghatározó, majd később e központi, kiemelt helyre más társasági funkciók is kerülhettek.

A lakórendeltetések túlsúlya a fó szinten továbbra is érvényesült, annak ellenére, hogy a létesíthető frekventált lakosztályok száma ezzel az új földszinti diszpozícióval 2-3-ra csökkent. E szám biztosítása érdekében a kéttraktusos vagy a kéttraktusos oldalfolyosós elrendezés általános volt a korszakban, melyben két lakosztály esetén az udvari traktus oldalfolyosóval kísért kiszolgáló zónává alakulhatott, míg három lakosztály létesítésekor egyet szükségszerúen az udvarra is tájolni kellett. A korabeli lakosztályok korábbi jellegzetességeket mutattak, nemek szerint tagolódtak, egy-egy hálószobából és kabinetekből álltak, körbejárhatók és elválasztott úton kiszolgálhatók voltak. Földszinti elhelyezésük miatt a belső kiszolgáló melléklépcsőjük természetesen elmaradt. A csákvári kastély női lakosztálya alatti, vagy a gyöngyösi földszinti férfi hálószoba melletti fürdőszoba ritka jelenségnek számított a korszakban.

A historizáló funkciószervezés és téralakítás fejlődésének legfontosabb állomása a differenciáltan kezelt földszinti lakó- és társasági terek mellérendelő kialakítása volt. Az 1770-90-es évek emeletes kompozícióiban lejátszódó folyamathoz hasonló zajlott az 1810-es években is, amikor a hagyományosnak tekinthető funkcionális szimmetria az épületbelsőben felbomlott, amely során a lakosztályok nemek szerinti tagolódása is megváltozhatott a közös hálószoba megjelenésével. A funkcionális módosulás fontos jelensége volt, hogy néhány a XVIII. században a lakosztályokba integrálódott vagy ahhoz kapcsolódó rendeltetés (biliárd, gyüjtemény stb.) ekkor a közösségi rendeltetések sorába került át, számukat jelentősen megnövelve. Az 1810-es évektől, pedig egyértelmúen a földszinti közösségi rendeltetések szervezése és feltárásának módja határozta meg a kastély belső struktúráját.

Az egyetlen tengelyre füzött társasági rendeltetéssor viszonylag kevés funkcionális elemmel is hamar hosszú és terjengős funkcionális csoportot eredményezett, $\mathrm{s}$ az ezt befoglaló térsor csak korlátozottan adta az egyre jobban elkülönülő és specializálódó funkcionális elemekhez igazodó változatos téralakítás lehetőségét. A 
korszakban hossz- vagy könyöktengelyre füzve önállóan formált, zárt formájú, centrális vagy négyzetes alaprajzú, fülkékkel bővített, oszlopokkal tagolt terek sorát találjuk.

A gyöngyösi kastély enfilade-tengelyre, illetve haránttengelyekre szimmetrikus, változatos formájú és összetett alaprajzú terei olyan hosszirányú térfüzéssel kapcsolódtak egymáshoz, mely egy súlyponti helyen - az oldalrizalitban - derékszögben megtört. Ezzel jóval összefogottabb - itt belső udvar köré szerveződő térkompozíció jöhetett létre, amelyet pedig már csak egy lépés választott el a XIX. század második felének következő jelentős belső-térszerkezeti újításától, Weber Antalnak (1823-1889) és Ybl Miklósnak (1814-1891) a társasági tereket funkciójuk szerint differenciált és monumentális csoportba foglaló térkompozícióitól, illetve ezek széleskörü elterjedésétől.

\section{FELHASZNÁLT IRODALOM}

Dercsényi-Koppány-Hegyi 1990 Dercsényi Balázs, Koppány Tibor, Hegyi Gábor: Magyar kastélyok. Budapest, Officina Nova, 1990.

Entz-Sisa 1998

Entz Géza Antal, Sisa József: Fejér megye müvészeti emlékei. Székesfehérvár, MTA Múvészettörténeti Kutató Intézet, Szent István Király Múzeum, 1998.

Haris-Pusztai 1988

Haris Andrea, Pusztai László: Révhelyi Elemér munkássága. Tata, Komárom Megyei Múzeumi Szervezet, 1988. (Tudományos füzetek 4.)

Horváth 1998

Horváth Hilda: Régvolt magyar kastélyok. Budapest, Gemini, 1998.

Jávor 1995

Bodnárné Jávor Éva: Új adatok Franz Anton Pilgram magyarországi működéséhez. Müvészettörténeti Értesitő XLIV. évf. 1995. 3-4. sz. 192-209.

Kardos-Révhelyi 1952

Kardos György, Révhelyi Elemér: A magyar barokk és zopf épitészet rövid összefoglalása. Budapest, A Tankönyvkiadó jegyzetsokszorosító üzeme, 1952. (Gépirat)

Kelényi 1974

Kelényi György: Kastélyok, kúriák, villák. Budapest, Corvina, 1974.

Krámer 1973

Gerőné Krámer Márta: Adatok a nagycenki volt Széchenyi-kastély építéstörténetéhez. Épités- Épitészettudomány V. köt. 1973. 3-4. sz. 479-487.

Novák 1836

Novák Dániel: Budavidéki utazás. Másod ízben. Hasznos mulatságok 1836. II. félév. 29-30. sz. 227-231, 235-240.

Örsi 1986

Rados 1931

Örsi Károly: A seregélyesi Zichy-Hadik kastély építéstörténete. Müemlékvédelem. XXX. évf. 1986. 3. sz. 203-208.

Rados Jenő: Magyar kastélyok. Budapest, MOB és Könyvbarátok Szövetsége, 1931. 
Rados 1939

Sisa 1981

Sisa 1994

Sisa 1997

Sisa 2005

Soós 2002

Sugár 1996

Voit 1943

Voit 1964

Voit 1978

Voit 1980

Wolf 1988

Zádor-Rados 1943

Zsámbéky 1994
Rados Jenő: Magyar kastélyok. Budapest, MOB, 1939. (Magyarország múvészeti emlékei IV.)

Sisa Béla: Békés megye müemlékei. I-II. köt., Békéscsaba, 1981. Sisa József: A bicskei Batthyány-kastély és Hild János. Müvészettörténeti Értesitö. XLIII. évf. 1994. 1-2. sz. 65-70.

Sisa József: A csákvári Esterházy-kastély. Müvészettörténeti Értesitö XLVI. évf. 1997. 1-2. sz. 1-42.

Sisa József: A dégi Festetics-kastély. Budapest, MÁG, 2005.

Soós István: Az alcsúti Habsburg-kastély tündöklése és pusztulása. Székesfehérvár, Szent István Király Múzeum, 2002.

Sugár István: Gróf Barkóczy Ferenc egri püspök Felsőtárkányban építtetett Fourcontrasti kastélya és annak 1761. július 17-i leltára. Müvészettörténeti Értesitö XLV. évf. 1996. 1-2. sz. 107-121.

Voit Pál: Régi magyar otthonok. H.n. [Budapest], Királyi Magyar Egyetemi nyomda, 1943.

Voit Pál: Beszámoló az OMF távlati kutatási tervéhez kapcsolódó levéltári munkáról. In: Magyar müemlékvédelem 1959-60. Budapest, Akadémiai Kiadó, 1964. 255-256.

Voit Pál: Heves megye müemlékei. III. köt. Budapest, Akadémiai Kiadó, 1978. (Magyarország múemléki topográfiája IX.)

Voit Pál: Barokk tervek és vázlatok 1650-1760. (Szerk.) Buzási Enikő. Budapest, Magyar Nemzeti Galéria, 1980. (Kiállítási katalógus)

Sándyné Wolf Katalin: Seregélyes, volt Zichy-Hadik-kastély helyreállítása. Müemlékvédelem XXXII. évf. 1988. 1. sz. 96-104.

Zádor Anna, Rados Jenő: A klasszicizmus épitészete Magyarországon. Budapest, MTA, 1943. 373-380.

Melchior Hefele (1716-1794) építész emlékkiállítása. Szerk.: Zsámbéky Monika. Szombathely, 1994.

\section{RÖVIDÍTÉSEK}

MÉM Magyar Építészeti Múzeum (Budapest)

MOL Magyar Országos Levéltár (Budapest)

SML Somogy Megyei Levéltár (Kaposvár) 


\section{REFORM OF THE REPRESENTATIVE SPACE-SYSTEM OF HUNGARIAN BAROQUE CASTLES BETWEEN THE 1750s AND 1840s Summary}

Analyzing the architecture of aristocratic residences between the 1750s and 1840s in Hungary, a transformational - developmental line can be found. It shows a transition from the hierarchical Baroque longitudinal method of space-ordering of the 18th century to the up-to-date central historizing space-compositions of the second half of the 19th century.

In the $1750 \mathrm{~s} 1760 \mathrm{~s}$, the carriage-entrance halls were taken over by the central sala terrena with the function of an entrance hall (Kiscenk, Gyula, Mór). At this time the main staircase still carried its significance in the space-composition, because the women's and guests' storey was henceforward the second floor. From the 1780s more frequently, but from the beginning of the 19th century nearly exclusively, the ground floor became the main storey (Csákvár). It caused necessarily a transformation in the disposition of the public and residential functions. The sala terrena in the main axis became an entrance-hall); whereas the main chamber connected to it henceforward played the role of the dining room.

The social and residential functions in the first quarter of the 19th century lined up in a longitudinal composition without hierarchical articulation with elements ordered next to each other (Bicske, Dég). Independent forming of the spaces and the separating of the residential and social functions were first used in this composition. It became possible to form more united space-ordering with breaking the axis of the space-ranging and with doubling the wing of the building (Gyöngyös). It was only one step away from the following important innovation in the internal space-structure in the middle of the 19th century, from the formation of the central space-compositions which united the social spaces in one monumental group.

Keywords: sala terrena, space-system, castle, typology sketch 
